\title{
The Wnt Effector Transcription Factor 7-Like 2 Positively Regulates Oligodendrocyte Differentiation in a Manner Independent of Wnt $/ \beta$-Catenin Signaling
}

\author{
Elizabeth Hammond, ${ }^{1 *}$ Jordan Lang, ${ }^{1 *}$ Yoshiko Maeda, ${ }^{1}$ CDavid Pleasure, ${ }^{1,2}$ Melinda Angus-Hill, ${ }^{5}$ Jie Xu, ${ }^{1}$ \\ Makoto Horiuchi, ${ }^{4}$ Wenbin Deng, ${ }^{1,3}$ and ${ }^{1}$ Fuzheng Guo ${ }^{1,2}$ \\ ${ }^{1}$ Institute for Pediatric Regenerative Medicine, Shriners Hospitals for Children, Sacramento, California 95817, Departments of ${ }^{2}$ Neurology, ${ }^{3}$ Biochemistry \\ and Molecular Medicine, and ${ }^{4}$ Pathology and Laboratory Medicine, School of Medicine, University of California, Davis, Sacramento, California 95817, and \\ ${ }^{5}$ Huntsman Cancer Institute, University of Utah, Salt Lake City, Utah 84112
}

Genetic or pharmacological activation of canonical Wnt/ $\beta$-catenin signaling inhibits oligodendrocyte differentiation. Transcription factor 7-like 2 (TCF712), also known as TCF4, is a Wnt effector induced transiently in the oligodendroglial lineage. A well accepted dogma is that TCF712 inhibits oligodendrocyte differentiation through activation of Wnt/ $\beta$-catenin signaling. We report that TCF7l2 is upregulated transiently in postmitotic, newly differentiated oligodendrocytes. Using in vivo gene conditional ablation, we found surprisingly that TCF712 positively regulates neonatal and postnatal mouse oligodendrocyte differentiation during developmental myelination and remyelination in a manner independent of the Wnt/ $\beta$-catenin signaling pathway. We also reveal a novel role of TCF7l2 in repressing a bone morphogenetic protein signaling pathway that is known to inhibit oligodendrocyte differentiation. Thus, our study provides novel data justifying therapeutic attempts to enhance, rather than inhibit, TCF712 signaling to overcome arrested oligodendroglial differentiation in multiple sclerosis and other demyelinating diseases.

Key words: BMP signaling; canonical Wnt/beta-catenin signaling; myelination; oligodendrocyte differentiation; remyelination; TCF7l2(TCF4)

\section{Introduction}

Transcription factor 7-like 2 (TCF7l2, also known as TCF4) is one of the four members of the TCF/LEF1 family (gene symbols, $T c f 7, T c f 7 l 1, T c f 7 l 2$, and Lef1 [lymphoid enhancer-binding factor $1]$ ) that are essential for mediating canonical Wnt $/ \beta$-catenin signaling in Wnt-activated cells (Fancy et al., 2010; Freese et al., 2010). During Wnt activation, TCF7l2 acts as an activator for Wnt target genes by which it regulates many Wnt-related biological processes. In the absence of Wnt activation, TCF712 interacts with co-repressors, such as Groucho, histone deacetylase, and other as yet unidentified factors, to repress gene expression in a context-dependent manner (Lien and Fuchs, 2014). TCF7l2 has a $\beta$-catenin-binding domain (encoded by exon 1 ) and a high mobility group-DNA binding domain (coded by exons 10 and 11), the latter of which is required for the function of TCF712 of both activating and repressing gene transcription (Lien and Fuchs, 2014). Among the four members of this group, only

\footnotetext{
Received Nov. 22, 2014; revised Feb. 13, 2015; accepted Feb. 18, 2015.

Author contributions: F.G. designed research; E.H., J.L., Y.M., J.X., and F.G. performed research; M.A.-H. and M.H. contributed unpublished reagents/analytic tools; E.H., J.L., D.P., W.D., and F.G. analyzed data; E.H.,J.L., D.P., M.A.H., W.D., and F.G. wrote the paper.

This work was supported by Shriners Hospitals for Children and the National Multiple Sclerosis Society.

*E.H. and J.L. contributed equally to this work.

Correspondence should be addressed to Fuzheng Guo, University of California, Davis, School of Medicine, c/o Shriners Hospitals for Children, 2425 Stockton Boulevard, Sacramento, CA 95817. E-mail: fzguo@ucdavis.edu. DOI:10.1523/JNEUROSCI.4787-14.2015

Copyright $\odot 2015$ the authors $\quad 0270-6474 / 15 / 355007-16 \$ 15.00 / 0$
}

TCF712 is expressed specifically in oligodendroglial lineage cells (Fancy et al., 2009; Fu et al., 2009; Ye et al., 2009).

Enforced activation of $\mathrm{Wnt} / \beta$-catenin signaling by genetic or pharmacologic manipulation inhibits or delays oligodendrocyte (OL) differentiation (Shimizu et al., 2005; Fancy et al., 2009, 2011, 2014; Feigenson et al., 2009; Ye et al., 2009; Lang et al., 2013; Dai et al., 2014). Because TCF7l2 is an essential effector for Wnt/ $\beta$-catenin signaling, the current well accepted hypothesis is that TCF712 inhibits oligodendrogenesis (Ye et al., 2009) and OL differentiation (He et al., 2007; Fancy et al., 2009, 2011; Li et al., 2009; Swiss et al., 2011; Sabo and Cate, 2013; Wood et al., 2013) through $\mathrm{Wnt} / \beta$-catenin activation. This hypothesis suggests that TCF7l2 expression in cells of the oligodendroglial lineage inhibits or delays OL differentiation and contributes to remyelination failure in the lesions of multiple sclerosis (Fancy et al., 2009; Pedre et al., 2011; Lürbke et al., 2013) and hypoxic ischemic encephalopathy (Fancy et al., 2011; Fu et al., 2012).

The specificity of TCF712 expression in oligodendroglial progenitor cells (OPCs) (Fancy et al., 2009, 2011, 2014) explained the specific activation of Wnt/ $\beta$-catenin signaling in OPCs and the inhibition of OPC differentiation into OLs when $\mathrm{Wnt} / \beta$-catenin is activated genetically. However, in a previous study, we reported that, when the Wnt negative regulator adenomatous polyposis coli (APC) is deleted conditionally, yielding $\mathrm{Wnt} / \beta$-catenin activation and OPC differentiation block, TCF712 is downregulated (Lang et al., 2013). This finding suggests that TCF7l2 may play a role in oligodendroglial lineage cells that is not involved in Wnt/ 
$\beta$-catenin signaling. Here we report that TCF712 is expressed intensely in myelin gene-expressing, newly differentiated OLs rather than in OPCs. Following up on these studies, we have used Cre-LoxP-mediated Tcf 72 gene ablation to demonstrate that TCF712 is, in fact, a positive regulator of neonatal and postnatal OL differentiation during both normal myelination and remyelination in a manner independent of Wnt/ $\beta$-catenin activity.

\section{Materials and Methods}

Transgenic mice. The transgenic mice Olig2-CreER ${ }^{T 2}, \mathrm{Plp}-\mathrm{CreER}{ }^{T 2}$, $C n p-C r e, A p c^{\mathrm{fl} / \mathrm{fl}}$, and $C t n n b 1^{\mathrm{fl} / \mathrm{fl}}$ (loxP sites located in introns 1 and 6 of $\beta$-catenin gene, loss-of-function) and the Wnt reporter strains Bat-LacZ and Axin2-LacZ are described in our previous study (Lang et al., 2013). $T c f 7 l 2^{\mathrm{fl} / \mathrm{fl}}$ (exon 1 is flanked by loxP sites) mice were kindly provided by Dr. Melinda Angus-Hill and are described in her previous study (AngusHill et al., 2011). Both male and female mice were used in this study. All mice were maintained on the C57BL/6 background and covered by Institutional Animal Care and Use Committee protocols approved by University of California, Davis.

Tamoxifen-induced Tcf 72 gene deletion. Tamoxifen was dissolved in $90 \%$ sunflower seed oil and $10 \%$ ethanol and freshly prepared at 30 $\mathrm{mg} / \mathrm{ml}$ solution.

For TCF712 conditional ablation in the early postnatal mice, tamoxifen was injected intraperitoneally with a dose of $100 \mu \mathrm{g} / \mathrm{g}$ body weight and with two injections at time points indicated in each figure according to our previous study (Lang et al., 2013). Control age-matched early postnatal mice $\left(T c f 7 l 2^{\mathrm{fl} / \mathrm{fl}}\right)$ were treated with tamoxifen in the same way as TCF712 conditional knock-out (cKO) mice. Our previous analysis, at $2 \mathrm{~d}$ after tamoxifen, indicated that OPCs were recombined predominantly in the spinal cord (Lang et al., 2013). Similarly, we have now found that, in the corpus callosum of Olig2-CreER ${ }^{T 2}$, Rosa-EYFP mice that received tamoxifen at P6 and P7, almost all tamoxifen-induced recombined cells were OPCs when analysis at P8.

For TCF712 conditional ablation in the cuprizone-induced demyelination model, 2-month-old adult Oligo2-CreER ${ }^{T 2}, T c f 72^{\mathrm{fl} / \mathrm{fl}}$ and $T c f 7 l 2^{\mathrm{fl} / \mathrm{fl}}$ control mice were injected intraperitoneally daily for 7 consecutive days from the end of the week 5 of cuprizone diet with a dose of 1.5 mg of tamoxifen per injection (for experimental design, see Fig. 9C).

Antibodies and $q P C R$ primers. Most antibodies used in this study have been described in our previous study (Lang et al., 2013). Four antiTCF712 antibodies were used in this study: (1) rabbit, clone C48H11 (catalog \#2569S; Cell Signaling Technology), recognizing DNA binding domain (Vacik et al., 2011); (2) rabbit, clone C9B9 (catalog \#2566S; Cell Signaling Technology), recognizing an N-terminal epitope around Glu81 (Vacik et al., 2011); (3) goat, polyclonal, C19 (catalog \#sc-8632; Santa Cruz Biotechnology), recognizing the C-terminal domain; and (4) mouse, clone 6H5-3 (catalog \#05-511; Millipore), raised against a recombined protein corresponding to residues 31-331 of human TCF712 (Barker et al., 1999). The clone 6H5-3 antibody (lot \#DAM1821079) gave a very high background when performing immunostaining on frozen sections without antigen retrieval and a clean background on paraffin sections; therefore, we used antigen retrieval when this antibody was used for immunohistochemistry (IHC) on frozen sections. All four TCF712 antibodies show the same immunostaining pattern, and the immunostaining signal was abolished in the TCF712 cKO mutants (see Fig. 5). Anti-phospho-Smad1/5 (Ser463/465) rabbit mAb 9516 was from Cell Signaling Technology. Mouse anti-BMP4 (MAB1049) was from Millipore. qPCR primers were all derived from the PrimerBank at pga.mgh.harvard.edu/primerbank/.

Primary OPC culture, tissue processing, IHC, $m R N A$ in situ hybridization, co-immunoprecipitation, Western blotting, $R T-q P C R$, confocal imaging, microarray, and induction of experimental autoimmune encephalomyelitis- and cuprizone-demyelination models. All these methods and procedures have been described in our previous studies (Guo et al., 2012; Lang et al., 2013).

Quantification and statistics. For cell counting, we obtained confocal images with $10 \mu \mathrm{m}$ optical thickness ( $12 \mu \mathrm{m}$ physical thickness sections were used for immunostaining) and projected into one flattened image. Images were taken from the same anatomic location from $\mathrm{cKO}$ and con- trol mice, and at least three histological sections were used from each animal. Cell counting and area calculation were conducted using confocal EZ-C1 viewer (Nikon). The cell density was calculated as the total number of cells counted divided by total area and expressed as cell number per square millimeter. For RT-qPCR quantification, the expression of genes of interest was normalized to that of internal control Hsp90, and the expression in controls was normalized to 1 . The statistics used in this study are indicated in each figure. All data were expressed as mean $\pm \mathrm{SD}$.

\section{Results}

\section{Wnt effector TCF712 is downregulated and LEF1 is} upregulated in oligodendroglial lineage cells of APC cKO animals

We reported previously that disruption of Wnt negative regulator APC blocks OL differentiation and that this differentiation blockage persists in the adult (Lang et al., 2013), a result consistent with a recent study (Fancy et al., 2014). Additional analysis showed that OPCs were blocked at the postmitotic neuron-glial antigen 2-negative $\left(\mathrm{NG}^{-}{ }^{-}\right) / \mathrm{PDGF}$ receptor $\alpha$-positive $\left(\mathrm{PDGFR}^{+}\right)$state and did not further differentiate into PDGFR $\alpha^{-} /$clone $\mathrm{CC}^{+}$ OLs in the APC cKO spinal cord of Olig2-CreER ${ }^{T 2}, A p c^{\mathrm{fl} / \mathrm{fl}}$ mice that received tamoxifen at $\mathrm{P} 6$ and $\mathrm{P} 7$ and were analyzed at P17 (data not shown).

APC is one of the components of the $\beta$-catenin destruction complex that is responsible for degrading cytoplasmic $\beta$-catenin, thus preventing activation of $\beta$-catenin-mediated canonical Wnt signaling (Aoki and Taketo, 2007). The Wnt target genes Sp5 (Fig. 1A; Boj et al., 2012; Fancy et al., 2014), Axin2, Naked1, and Notum, among other potential candidates of Wnt target genes (Table 1), were upregulated significantly in the spinal cord of APC cKO mice. Surprisingly, however, the Wnt effector TCF712 was downregulated at both mRNA and protein levels (Fig. $1 B-D$ ).

These seemingly conflicting observations of upregulation of $\mathrm{Wnt} / \beta$-catenin activity and downregulation of TCF712 prompted us to investigate what other Wnt effectors are upregulated to mediate Wnt/ $\beta$-catenin signaling in APC $\mathrm{cKO}$ oligodendroglial lineage cells. Of mRNAs encoding the four members of the TCF/ LEF1 family, only LEF1 mRNA was upregulated significantly in APC cKO mice (Fig. 1E). Consistent with this finding, LEF1 was upregulated significantly in Sox $10^{+}$oligodendroglial lineage cells in APC cKO mice (Fig. $1 H$ ), in line with a recent publication (Fancy et al., 2014), whereas in APC wild-type (WT) controls, LEF1 was absent in Sox $10^{+}$oligodendroglial lineage cells and only expressed in platelet endothelial cell adhesion molecule positive $\left(\mathrm{PECAM}^{+}\right.$) endothelial cells (Fig. $1 F, G$ ). These data indicate that induction of LEF1 in oligodendroglial lineage cells may be responsible for the overactivation of $\mathrm{Wnt} / \beta$-catenin signaling elicited by APC cKO. Supporting this notion, we found that Axin 2 mRNA, a reliable readout of $\mathrm{Wnt} / \beta$-catenin activation, was barely detectable in TCF7l2 ${ }^{+}$cells in APC WT (Fig. 1I) and upregulated in $\mathrm{LEF} 1^{+} /$Sox $10^{+}$cells in APC cKO (Fig. $1 J$ ). The inhibition of OPC differentiation into OLs and downregulation of TCF712 in APC cKO led us to hypothesize that TCF7l2 is upregulated in cells that are developmentally downstream of "stalled" OPCs, and thus the downregulation of TCF712 in APC cKO simply reflects the blockage of OPC differentiation. We next investigated the cellular specificity of TCF712 expression during OL differentiation.

\section{TCF712 is upregulated transiently in newly differentiated, premyelinating OLs during normal development}

TCF712 was reported previously to be expressed more intensely in OPCs and then downregulated in OLs (Fancy et al., 2009, 2011). 

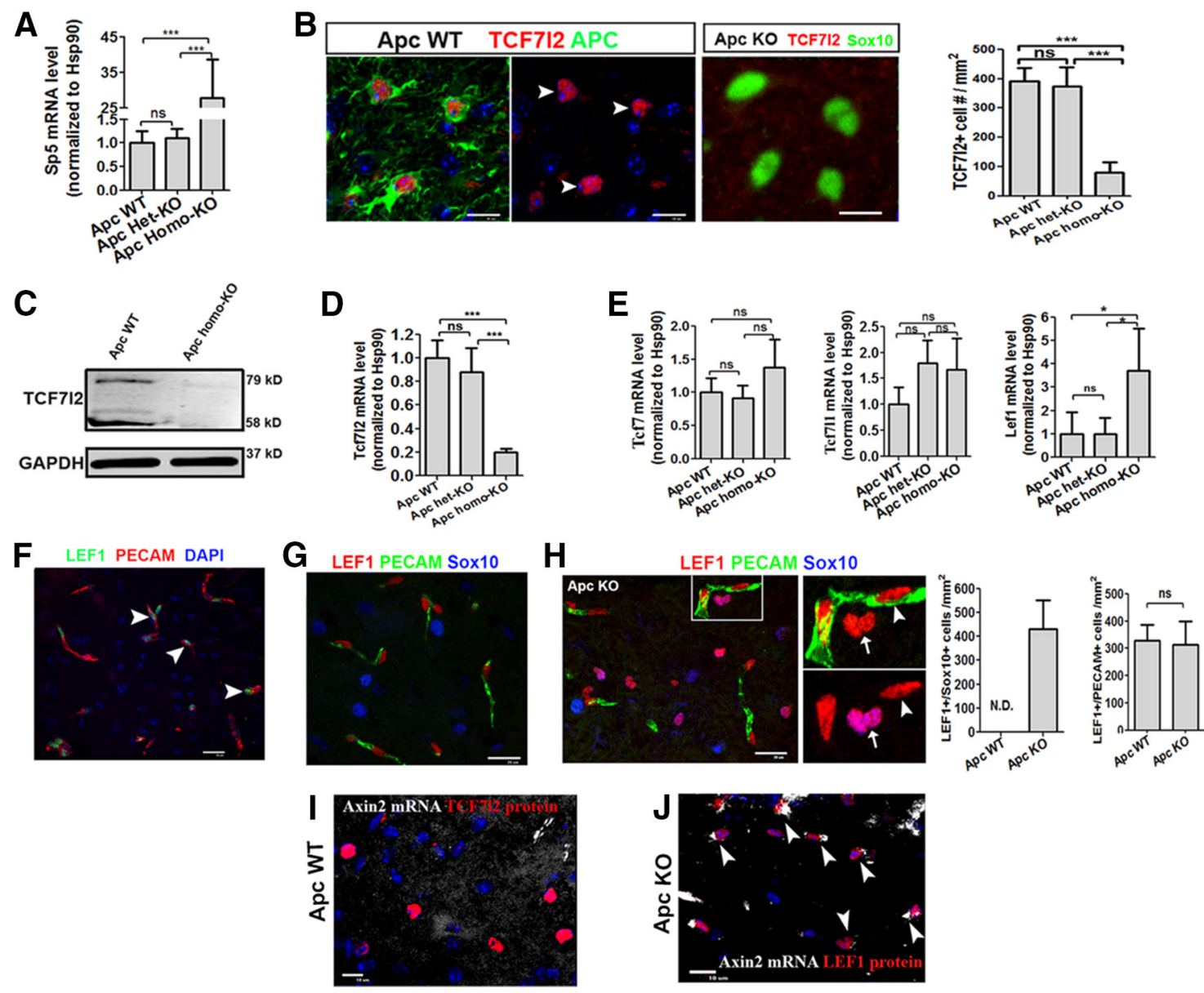

Figure 1. Wnt effector TCF7I2 is downregulated and LEF1 is upregulated in APC cK0 mutants. A, RT-qPCR of mRNA expression of generic Wnt target Sp5 in APC WT, APC heterozygous (Het) K0 (Olig2-CreER ${ }^{T 2}, A p C^{\mathrm{fl} /+}$ ), and APC homozygous (Homo) KO (Olig2-CreER ${ }^{T 2}, A p c^{\mathrm{fl} / f 1} \cdot n=4$ in each group. $B$, Representative confocal images of TCF7I2 and APC double IHC and density of TCF7l2 ${ }^{+}$ cells. $n=4$ in each group. C,-D, Western blot of TCF712 and RT-qPCR quantification of Tcf712 mRNA expression. $n=10$ in WT, 6 in APC Het-K0, and 7 in APC Homo-K0. E, mRNA levels of TCF7, TCF7l1, and LEF1 quantified by RT-qPCR. $n=4$ in each group. $F, G$, Representative confocal images of IHC of LEF1 and PECAM $(\boldsymbol{F})$ and LEF1, PECAM, and Sox10 (G). Arrowheads in $\boldsymbol{F}$ point to LEF1 ${ }^{+}$cells that are PECAM ${ }^{+}$endothelial cells in APCWT spinal cord. Note that all LEF1 ${ }^{+}$cells are positive for PECAM and negative for Sox 10 in the APC WT spinal cord (G). $\boldsymbol{H}$, Representative confocal images of IHC of LEF1, PECAM, and Sox10 in APC K0 spinal cord and their quantification. Boxed area in $\boldsymbol{H}$ is shown at higher power at the right. Arrows point to LEF ${ }^{+} / \mathrm{Sox}_{0} 0^{+}$cells, and arrowheads point to LEF $1^{+} /$PECAM ${ }^{+}$cells. $n=4$ in each group. $I, J$, Dual ISH of Axin2 and IHC of TCF7I2 or LEF1 in the spinal cord of APC WT $(I)$ and APC KO $(J)$ at P14. Arrowheads in $J$ point to double-positive cells. TCF712 protein is undetectable by IHC in APC KO attributable to the downregulation in APC KO. All data in Figure 1 were collected from spinal cord tissue. Tamoxifen was injected to each group at P7 and P8 daily, and the spinal cord was analyzed at P14. One-way ANOVA with Bonferroni's post hoc test $(\boldsymbol{A}, \boldsymbol{B}, \boldsymbol{D}, \boldsymbol{E})$. Two-tailed Student's $t$ test $(\boldsymbol{H}){ }^{*} p<0.05,{ }^{* *} p<0.01$, ${ }^{* * *} p<0.001$. Scale bars: $B, 25 \mu \mathrm{m} ; \boldsymbol{F}-H, 30 \mu \mathrm{m} ; \boldsymbol{I}, \mathbf{J}, 10 \mu \mathrm{m}$.

Using purified primary OPC cultures derived from neonatal rat forebrain, we found that TCF712 mRNA was low in OPCs, was sharply upregulated when purified OPCs were cultured in differentiation medium for $1 \mathrm{~d}$, but then was downregulated after $4 \mathrm{~d}$ of differentiation to mature OLs (Fig. 2A). Western blot data confirmed this temporal pattern of TCF712 expression during OPC differentiation and maturation (Fig. 2B). (Note that two differently sized isoforms of TCF7l2 were detected, one at $58 \mathrm{kDa}$ and one at $79 \mathrm{kDa}$.) In vivo, TCF7l2 was barely detectable in NG2 ${ }^{+}$or PDGFR $\alpha^{+} /$Sox $10^{+}$OPCs in the spinal cord (Fig. $2 C$, left) and forebrain (Fig. $2 C$, right) but intensely expressed in $\mathrm{CC}^{+}{ }^{+}$differentiated OLs in spinal cord (Fig. 2D, left), forebrain (Fig. 2D, middle), and cerebellum (Fig. $2 D$, right). We validated the specificity of the TCF712 antibodies we used by demonstrating that their binding was abolished in TCF7l2 cKO tissue (see Fig. 5). Consistent with the temporal pattern in vitro (Fig. 2A,B), TCF712 expression was downregulated in the adult CNS (data not shown) in which most OLs are mature, thus resembling the temporal pattern we reported previously for APC expression (Lang et al., 2013).
We further demonstrated that TCF712 was upregulated transiently in postmitotic, newly differentiated myelin geneexpressing OLs (Fig. $3 H$ ). All TCF712 ${ }^{+}$cells were positive for myelin basic protein (MBP; Fig. $3 A, B$, arrowheads) and $2^{\prime}, 3^{\prime}$ cyclic nucleotide 3 '-phosphodiesterase (CNP; Fig. 3C, arrowheads) in their cell bodies and proximal processes, and all $\mathrm{MBP}^{+}$ and $\mathrm{CNP}^{+}$myelin gene-expressing OLs were positive for nuclear TCF712 in the spinal cord at late embryonic and very early postnatal stages when mature, myelinating OLs are sparse. Using a combination of mRNA in situ hybridization (ISH) and IHC, we demonstrated that all TCF712 ${ }^{+}$cells were positive for mRNA of $M b p$ (Fig. 3D, arrowheads) and proteolipid protein ( $P l p$; Fig. $3 E$, arrowheads) in the spinal cord at $\mathrm{P} 7$ when active myelination occurs. However, a large proportion of $M b p$ or Plp mRNA $^{+}$cells were negative for TCF7l2 at this later time point (Fig. $3 D, E$, arrows), indicating that these cells were more mature, myelinating OLs that had downregulated TCF712. Consistent with their differentiated status, all $\mathrm{TCF} 2^{+}$cells were Ki67 ${ }^{-}$and did not divide during $2 \mathrm{~h}$ pulse 5-ethynyl-2-deoxyuridine (EdU) labeling (Fig. 3F, G). Collectively, 
Table 1. Significantly upregulated genes in the spinal cord of APC KO (Olig2-CreER ${ }^{T 2}, A p c^{\mathrm{fl} / \mathrm{fl}}$ ) compared with $A p \mathrm{c}^{\mathrm{f} / / \mathrm{fl}}$ littermate controls from gene array analysis

\begin{tabular}{|c|c|}
\hline Gene symbol & Fold up \\
\hline Mybpc1 & 3.3 \\
\hline Nkd1 & 2.7 \\
\hline Cxcr4 & 2.5 \\
\hline Rpgr & 2.1 \\
\hline Tnfrsf19 & 2.1 \\
\hline E2f8 & 1.9 \\
\hline Npy & 1.9 \\
\hline Rnf43 & 1.9 \\
\hline Sp5 & 1.9 \\
\hline Gpr64 & 1.8 \\
\hline Esyt3 & 1.8 \\
\hline Axin2 & 1.7 \\
\hline Nptx2 & 1.7 \\
\hline C1qtnf1 & 1.6 \\
\hline Wif1 & 1.5 \\
\hline Kctd12 & 1.5 \\
\hline Cdh3 & 1.5 \\
\hline Gpr31b & 1.5 \\
\hline Esr1 & 1.5 \\
\hline Notum & 1.5 \\
\hline Gpr31c & 1.5 \\
\hline Hmgcs2 & 1.4 \\
\hline Apcdd1 & 1.4 \\
\hline Depdc2 & 1.4 \\
\hline Abhd2 & 1.4 \\
\hline Clic6 & 1.4 \\
\hline Slc24a4 & 1.4 \\
\hline Mr1 & 1.4 \\
\hline Lef1 & 1.4 \\
\hline Prmt8 & 1.3 \\
\hline Uevld & 1.3 \\
\hline Ptprm & 1.3 \\
\hline Сур26b1 & 1.3 \\
\hline Abca1 & 1.3 \\
\hline Fzd1 & 1.3 \\
\hline Wwc1 & 1.3 \\
\hline Akna & 1.3 \\
\hline $01 f m 2$ & 1.3 \\
\hline $\mathrm{Ndn}$ & 1.3 \\
\hline ВС057079 & 1.3 \\
\hline SIc1a3 & 1.3 \\
\hline ВС062109 & 1.3 \\
\hline Nebl & 1.3 \\
\hline Pde1a & 1.3 \\
\hline Syngap1 & 1.3 \\
\hline $\mathrm{Hen} 4$ & 1.3 \\
\hline ||16 & 1.3 \\
\hline Gsg1l & 1.3 \\
\hline Rnf144b & 1.3 \\
\hline Egr1 & 1.3 \\
\hline
\end{tabular}

These genes are potential candidates of Wnt-regulated genes in oligodendroglial lineage cells. Genes marked in bold are components of the Wnt/ $\beta$-catenin signaling pathway or known Wnt target genes. APC was conditionally ablated in mice by tamoxifen injection at $\mathrm{P} 6$ and $\mathrm{P} 7$ (1 injection per day), and spinal cord tissue was harvested on $P 14 . n=4$ in each group, $p<0.05$ with false discovery rate correction. Only genes with a minimal upregulation of 1.3-fold in Olig2-CreER ${ }^{T 2}, A p c^{\mathrm{fl} / \mathrm{fl}}$ mice are shown here.

our data support the hypothesis that TCF712 is upregulated transiently in myelin gene-expressing, newly differentiated OLs rather than in OPCs.

Expression of TCF712 in oligodendroglial lineage cells is not associated with the activation of Wnt/ $\beta$-catenin signaling Next we asked whether TCF7l2 expression in OLs is an indicator of the activation of canonical $\mathrm{Wnt} / \beta$-catenin signaling. To this end, we systematically analyzed the temporal dynamics of the Wnt reporter $\beta$-galactosidase $(\beta$-gal) and endogenous TCF712 within Sox $10^{+}$oligodendroglial lineage cells (Fig. 4A) in BatLacZ transgenic mice (Maretto et al., 2003) in which Wnt reporter $\beta$-gal expression is induced during the binding of the $\beta$-catenin/TCF/LEF1 complex to the binding site within the transgenic promoter region. The density of TCF7l $2^{+} /$Sox $10^{+}$ cells was increased significantly in the spinal cord of Wnt reporter mice from P1 (initiation of OPC differentiation) to P7 (peak of OPC differentiation and myelination; Fig. $4 B$ ). Conversely, the density of $\beta$-gal ${ }^{+} / \mathrm{TCF} 712^{+} /$Sox $10^{+}$cells (Wnt-active cells) in the spinal cord of these mice was decreased significantly from $\mathrm{P} 1$ to P7 (Fig. $4 B$ ). Of note, TCF7l2 ${ }^{+}$cells were rarely $\beta$-gal ${ }^{+}$in the spinal white matter (WM) by P10, although TCF712 ${ }^{+}$cells maintained a high density $\left[456 \pm 59 / \mathrm{mm}^{2}\right.$ (mean $\pm \mathrm{SD}$ ) compared with $435 \pm 75 / \mathrm{mm}^{2}$ in P1; Fig. $4 B$ ]. A total of $17.9 \%$ of total Sox $10^{+}$oligodendroglial lineage cells were $\beta$-gal ${ }^{+}$in the spinal $\mathrm{WM}$ at P1 (Fig. 4C), consistent with a previous publication (Fancy et al., 2009). However, this percentage decreased to $2.5 \%$ by $\mathrm{P} 7$ and $0.7 \%$ by $\mathrm{P} 10$, and $\beta$-gal ${ }^{+}$cells were virtually absent by $\mathrm{P} 14$ in spinal cord WM (Fig. 4C). Interestingly, many $\beta$-gal ${ }^{+}$cells were $\mathrm{NeuN}^{+}$neurons in the dorsal horn gray matter (GM) and ependymal cells surrounding the central canal at each time point (data not shown). In the forebrain of Bat-LacZ mice, few $\mathrm{TCF}_{12}{ }^{+}$cells were $\beta$-gal ${ }^{+}$(Fig. $4 D$, arrows), although $\beta$-gal ${ }^{+}$ cells were observed frequently in the P7 corpus callosum (Fig. $4 D$, arrowheads). As a positive control, we observed that many TCF7l2 ${ }^{+}$neurons in the thalamus, which are known to be subject to $\mathrm{Wnt} / \beta$-catenin activation (Wisniewska et al., 2012), were $\beta$-gal ${ }^{+}$(data not shown).

In an autoimmune model of multiple sclerosis, myelin oligodendrocyte glycoprotein (MOG)-peptide experimental autoimmune encephalomyelitis (EAE; Guo et al., 2011, 2012), we observed that TCF712 was significantly reinduced in Sox $10^{+}$ newly differentiated OLs at both mRNA and protein levels on days 21 and 68 of post-MOG-peptide immunization (Fig. 4E,F), although the absolute density of TCF7l2 ${ }^{+}$cells was much lower than that during developmental myelination. Of note, most TCF7l2 ${ }^{+}$cells were distributed within and surrounding the inflammatory demyelinative lesions (Fig. $4 F$, dotted areas). However, mRNA expression of the endogenous Wnt target genes Axin2, Naked1, Notum1, and Lef1 were not increased at either of these time points (Fig. 4G,H). We further demonstrated that mRNA expression of Wnt reporter LacZ, which provides a more precise, real-time indicator for $\mathrm{Wnt} / \beta$-catenin activation than $\beta$-gal protein (LacZ gene product; Fancy et al., 2011), was similar between Bat-LacZ mice treated with MOG and those treated with complete Freund's adjuvant (CFA) control on both days 21 and 68 after EAE (Fig. 4I). Using an independent Wnt reporter strain Axin2-LacZ, we showed that the mRNA expression of transgenic LacZ and endogenous Wnt target genes Axin 2 and Naked 1 were also similar between MOG-treated and CFA-treated mice on day 21 after EAE (Fig. $4 J$ ). At the histological level, $\beta$-gal ${ }^{+}$cells were virtually absent from WM and mainly located in the dorsal horn GM (Fig. $4 K$ ) and ependymal cells (data not shown) at comparable levels in both MOG- and CFA-treated mice.

The conclusion that TCF712 induction was not associated with the activation of $\mathrm{Wnt} / \beta$-catenin signaling was further supported by analyzing TCF712 and $\beta$-gal expression in the cuprizone demyelination model. Six weeks after initiating the cuprizone diet in Bat-LacZ mice, there was robust induction of TCF7l2 expression in the corpus callosum (Fig. $4 L$, left), with much higher numbers of TCF712 ${ }^{+}$cells than those in the spinal 


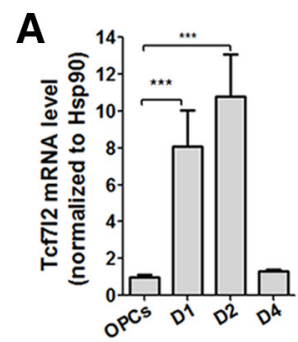

B

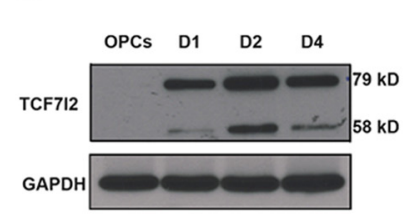

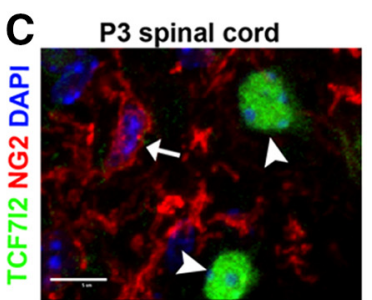

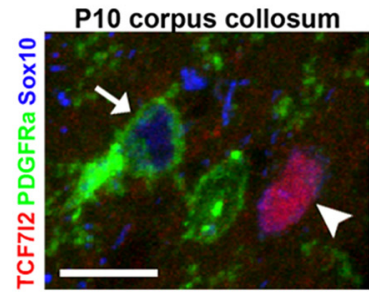

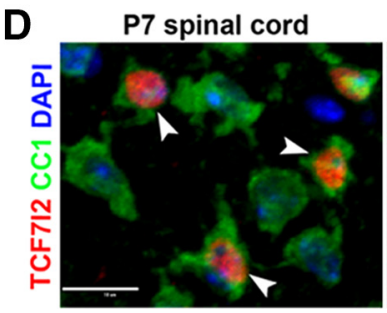

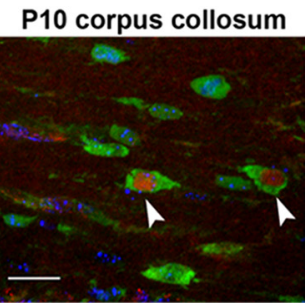

P10 cerebellar WM

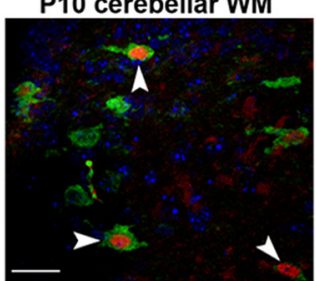

Figure 2. TCF7/2 is upregulated in $0 \mathrm{Ls}$ both in vitro and in vivo. $\boldsymbol{A}, \boldsymbol{B}, \mathrm{TCF} 7 \mathrm{I} \mathrm{mRNA}(\mathrm{RT}-\mathrm{QPCR} ; \boldsymbol{A})$ and protein (Western blot; $\boldsymbol{B}$ ) expression in purified primary OPCs (from neonatal rat cortex) and their differentiated progenies at days 1-4 (D1-D4). $n=4$ at each time point. C, Representative confocal images of IHC of TCF712 and NG2 (left) and TCF712, PDGFR $\alpha$, and Sox10 (right). Arrows point to NG2 ${ }^{+}$or PDGFR $\alpha^{+}$OPCs with extremely low levels of TCF7I2. Arrowheads point to TCF712 ${ }^{+}$cells that are NG2 ${ }^{-}$or PDGFR $\alpha^{-}$. D, IHC showing TCF7I2 expression in CC1 ${ }^{+}$differentiated $0 \mathrm{LL}$ (arrowheads) in the spinal cord, corpus callosum, and cerebellar WM. One-way ANOVA with Bonferroni's post hoc test. ${ }^{* * *} p<0.001$. Scale bars: C, left, $5 \mu \mathrm{m}$; all others, $10 \mu \mathrm{m}$.

cord of MOG-EAE mice. However, few TCF712 ${ }^{+}$cells were $\beta$-gal ${ }^{+}$, although $\beta$-gal was strongly expressed in the hippocampus (Fig. $4 L$, right, arrowhead) in which $\mathrm{Wnt} / \beta$-catenin signaling is active (Lie et al., 2005). Collectively, our in vivo data support the hypothesis that TCF712 expression in newly differentiated OLs is not associated with the activation of $\mathrm{Wnt} / \beta$-catenin signaling in vivo during both developmental myelination and remyelination.

\section{TCF712 cKO inhibits postnatal OL differentiation during normal myelination}

Previous studies proposed that TCF712 may inhibit oligodendroglial differentiation (He et al., 2007; Fancy et al., 2009). However, this hypothesis is difficult to reconcile with the observation that there are fewer differentiated OLs in the spinal cord of Tcf7l2-null late embryos or newborns (Fu et al., 2009; Ye et al., 2009). Based on our data, we hypothesized that TCF712 promotes OL differentiation during postnatal myelination in the CNS. To test this hypothesis, we used the Cre-loxP system to conditionally ablate TCF712 in oligodendroglial lineage cells, thus circumventing the lethality of Tcf7l2-null newborns (Boj et al., 2012).

We first used inducible Olig2-CreER ${ }^{T 2}$ (Lang et al., 2013) and Tcf7l2 exon 1 floxed (Angus-Hill et al., 2011) strains to delete the TCF712 exon 1 sequence in OPCs (Fig. 5A,C). Using Olig2-Cre$E R^{T 2}, R o s a-E Y F P$ reporter mice, we had reported previously that, in the spinal cord, $75 \%$ of EYFP ${ }^{+}$recombined cells were OPCs when tamoxifen was injected at P6 and P7 and analysis was at P8 (Lang et al., 2013). These percentages of recombined OPCs were likely underestimated, because some of the initially recombined OPCs (at P6) probably would have differentiated into OLs by the time of tissue analysis (at P8) during this active oligodendroglial differentiation stage in spinal cord. Therefore, these data suggest that the deletion of Tcf7l2 exon 1 was initiated predominantly in OPCs in the Olig2-CreER ${ }^{T 2}, T c f 7 l 2^{\mathrm{fl} / \mathrm{fl}}$ mutants. We showed that Cre-mediated deletion of $T c f 7 l 2$ exon 1 (Fig. $5 C$ ) abolished the potential truncated TCF712 protein in OLs that contains a DNA binding domain (Fig. 5D), an $\mathrm{N}$-terminal domain (Fig. $5 E$ ), and a C-terminal domain (Fig. 5F; see antibodies in Materials and Methods), which is consistent with a previous publication
(Angus-Hill et al., 2011), thus eliminating the dominant-negative effects of residual TCF712 in our study.

Deletion of the TCF712 exon 1 sequence initially in OPCs caused hypomyelination in the forebrain (Fig. 5G), spinal cord (Fig. $5 H$ ), and cerebellum (Fig. $5 I$ ), suggesting the hypothesis that TCF712 functions as a positive regulator of OL differentiation. Supporting this hypothesis, we found that conditional deletion of TCF712 starting at P6 (Fig. 6A) diminished the density of $\mathrm{CC}^{+}{ }^{+} \mathrm{OLs}$ in the spinal cord of Olig2-CreER ${ }^{T 2}, T c f 7 l 2^{\mathrm{fl} / \mathrm{fl}} \mathrm{mu}-$ tants compared with $T c f 7 l 2^{\mathrm{fl} / \mathrm{fl}}$ controls at P14, whereas the density of $\mathrm{NG}^{+}$OPCs was not changed (Fig. $6 B, C$ ). Using mRNA ISH, we observed fewer $M b p$ mRNA $^{+}$and $P l p$ mRNA ${ }^{+}$differentiated OLs in the spinal cord of Olig2-CreER ${ }^{T 2}, T c f 7 l 2^{\mathrm{fl} / \mathrm{fl}}$ mice compared with littermate controls (Fig. 6D). The mRNA levels of Sox10 and the myelin genes Plp, Cnp, and Mbp were all significantly diminished, whereas mRNAs coding the OPC markers NG2 and PDGFR $\alpha$ did not change in Olig2-CreER ${ }^{T 2}, T c f 7 l 2^{\mathrm{fl} / \mathrm{fl}}$ mice by RT-qPCR quantification (Fig. 6E). Microarray analysis demonstrated that the expression of the myelin genes Opalin, myelin-associated glycoprotein (Mag), myelin-associated oligodendrocyte basic protein (Mobp), Mog, Cnp, Mbp, and Plp were all significantly decreased in Olig2-CreER ${ }^{T 2}, T c f 7 l 2^{\mathrm{fl} / \mathrm{fl}}$ mice compared with those in $T c f 7 l 2^{\mathrm{fl} / \mathrm{fl}}$ littermate controls (Table 2, genes marked in bold). A cell proliferation assay revealed that the inhibition of OL differentiation was not attributable to a diminution in mitotic rate of TCF712-ablated OPCs (Fig. 6F), nor to increased apoptosis of differentiated OLs (data not shown). Together, these data suggest that TCF712 promotes OL differentiation during developmental myelination.

To exclude any potential side-effects of tamoxifen on CNS development and to substantiate the conclusion derived from Olig2-CreER ${ }^{T 2}, T c f 7 l 2^{\mathrm{fl} / \mathrm{fl}}$ transgenic mice, we used the constitutive Cre driver Cnp-Cre (Lappe-Siefke et al., 2003), which is activated initially in OPCs and remains activated persistently in differentiated OLs. Cnp-Cre, $T c f 7 l 2^{\mathrm{fl} / \mathrm{fl}}$ mutants were born in a normal Mendelian ratio and had no TCF712 expression in the spinal cord (Fig. 6G), cerebellum, and corpus callosum of the forebrain (data not shown). Histological and molecular quantification demonstrated that $C n p-C r e, T c f 7 l 2^{\mathrm{fl} / \mathrm{fl}}$ mice contained 

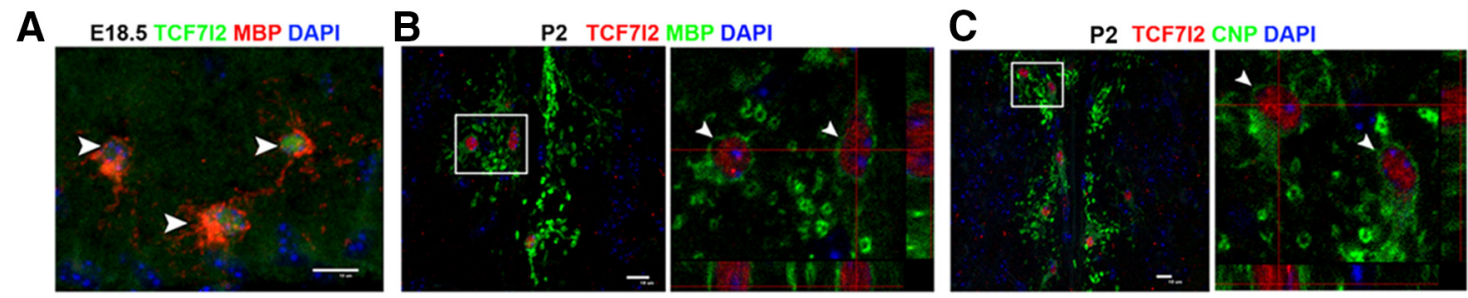

D
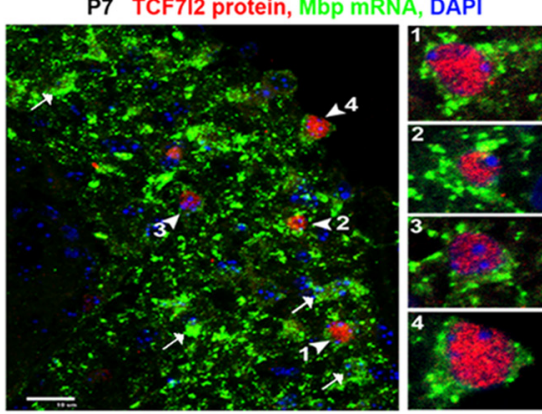

E
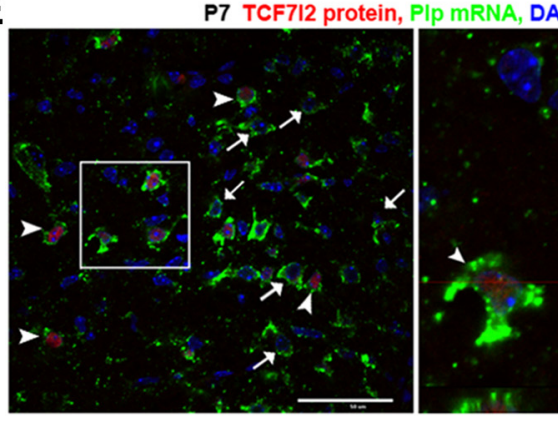

$F$
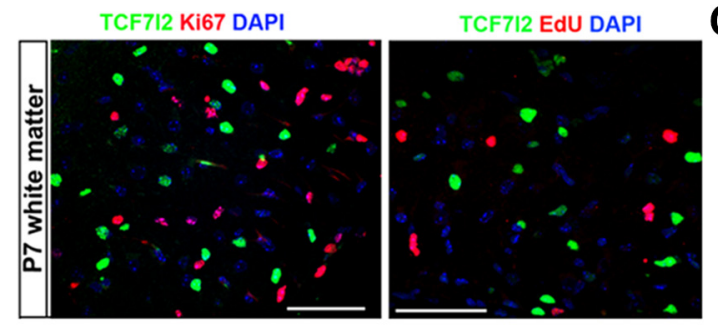

G

TCF7I2 Ki67 DAPI
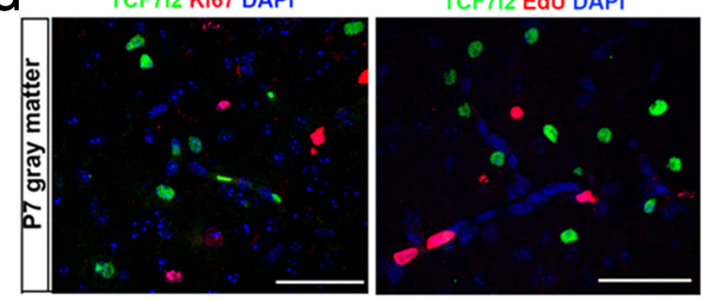

H

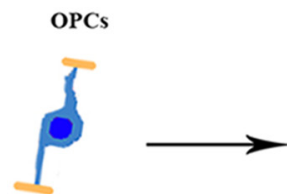

immature OLs

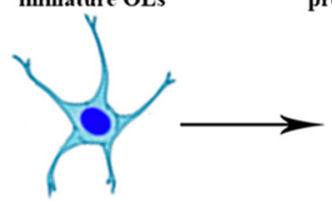

remyelinating OLs

myelinated OLs

NG2 high PDGFRa high APC low TCF712 low No myelin gene
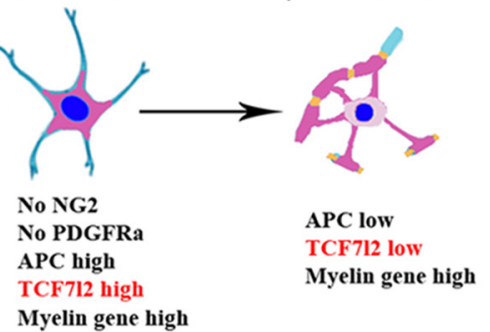

Figure 3. TCF7l2 is expressed in postmitotic newly differentiated premyelinating $0 \mathrm{LS}$. $\boldsymbol{A}-\boldsymbol{C}$, Double IHC of TCF7l2 and MBP or CNP in the spinal cord at E18.5 or P2. The boxed areas in $\boldsymbol{B}$ and $\boldsymbol{C}$ are shown as high-power orthogonal images at the right. Arrowheads point to $\mathrm{TCF} \mathrm{I} 2^{+}$cells that express MBP or CNP in the cell bodies and proximal processes, which are characteristic of newly differentiated, premyelinating 0 Ls. $\boldsymbol{D}, \boldsymbol{E}$, IHC of TCF7I2 protein and ISH of $M b p(\boldsymbol{D})$ or PIp $(\boldsymbol{E}) \mathrm{mRNA}$ in P7 spinal cord. Cells pointed by arrowheads $1-4$ in $\boldsymbol{D}$ and boxed area in $\boldsymbol{E}$ are shown as high-power images at the right. Note that all TCF7I2 ${ }^{+}$cells are Mbp or Plp mRNA ${ }^{+}$(arrowheads), whereas a large proportion of Plp or Mbp mRNA ${ }^{+}$cells at this age are TCF7I2 ${ }^{-}$(arrows). F, G, Double IHC of TCF7l2 and Ki67 or EdU ( $2 \mathrm{~h}$ pulse labeling) in the spinal cord. $\boldsymbol{H}$, Schematic drawing depicting the temporal dynamics of TCF7l2 expression during OL development: low expression in OPCS, upregulation in postmitotic, newly differentiated, premyelinating $0 \mathrm{Ls}$, and downregulation in mature, myelinating $0 \mathrm{Ls}$. Scale bars: $\boldsymbol{A}-\boldsymbol{D}, 10 \mu \mathrm{m} ; \boldsymbol{E}-\mathbf{G}, 50 \mu \mathrm{m}$.

fewer Plp mRNA ${ }^{+}, M b p$ mRNA ${ }^{+}$cells (Fig. $6 H, I$ ) and fewer Sox $10^{+} / \mathrm{CC} 1^{+}$differentiated OLs (Fig. $6 J$ ) in the spinal cord compared with $T c f 72^{\mathrm{fl} / \mathrm{fl}}$ littermate controls at $\mathrm{P} 5$ when active OL differentiation occurs. Consistent with the data from Olig2-Cre$E R^{T 2}, T c f 72^{\mathrm{f} / / \mathrm{fl}}$ mutants (Fig. $6 \mathrm{~A}-\mathrm{F}$ ), numbers of Sox $10^{+} / \mathrm{CC} 1^{-}$ undifferentiated OPCs and mRNA levels of the OPC markers NG2 and Pdgfr $\alpha$ and of the cell-cycle regulator Cyclin D1 were not altered in Cnp-Cre, Tcf7l2 $2^{\mathrm{f} / \mathrm{fl}}$ mice (Fig. $6 I, J$ ). Collectively, these in vivo data from different Cre-loxP mutants provide compelling evidence indicating that the Wnt effector TCF7l2 is a required positive regulator for OL differentiation.

\section{TCF712 expression in differentiated OLs does not regulate} myelin gene expression

A previous study reported that $\mathrm{Wnt} / \beta$-catenin signaling through TCF7l2 in $P l p^{+}$OLs directly activates myelin gene expression in zebrafish embryonic CNS (Tawk et al., 2011). The observation that TCF712 is upregulated transiently in newly differentiated, myelin gene-expressing OLs (Fig. 3) prompted us to determine whether the transcription factor TCF712 directly regulates myelin gene expression in $\mathrm{Plp}^{+}$OLs. To this end, we used Plp-CreER ${ }^{T 2}$ to delete TCF712 predominantly in $P l p^{+}$differentiated OLs by tamoxifen treatment. The cellular specificity of $P l p-C r e E R^{T 2}$ depends on the time of tamoxifen injection (Doerflinger et al., 2003; Guo et al., 2009, 2012; Harlow et al., 2014). Our previous studies showed that a small proportion of OPCs $(\sim 10 \%$ among total OPCs) were recombined with EYFP in the spinal cord when tamoxifen was injected at very early postnatal ages (Guo et al., 2009). However, EYFP was predominantly expressed in differentiated OLs in the spinal cord when tamoxifen was injected at adult ages (Guo et al., 2012). Here we show that EYFP is predominantly expressed in $\mathrm{CC}^{+}$differentiated OLs in the spinal cord of Plp$C r e E R^{T 2}, T c f 72^{\mathrm{f} / / \mathrm{fl}}$, Rosa-EYFP triple transgenic mice (Fig. 7A2) when tamoxifen was injected at P9 (Fig. 7A1). TCF712 expression 
A

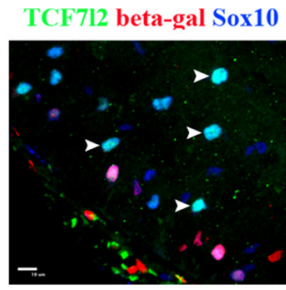

D

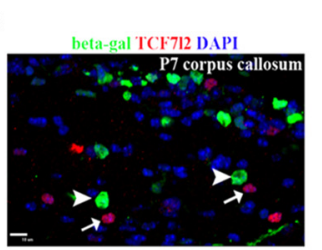

G
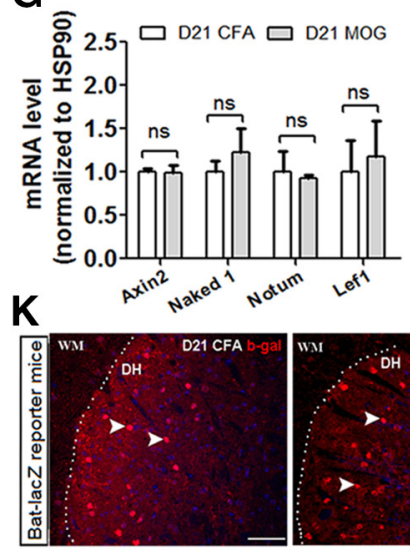

B

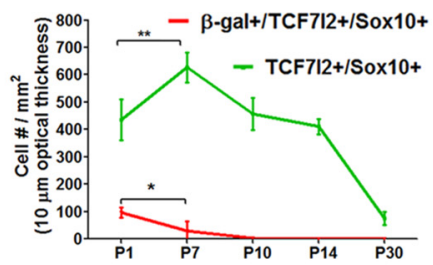

C

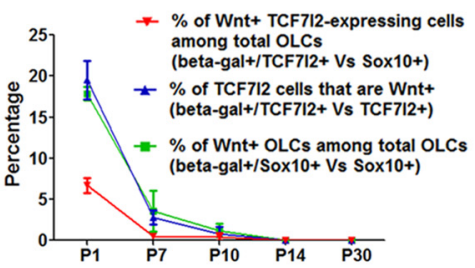

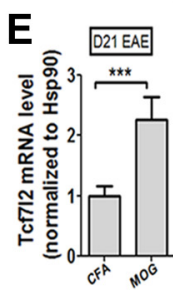

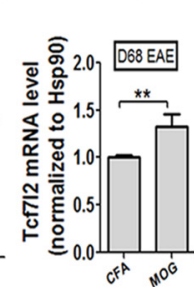

$F$
$\mathbf{H}$

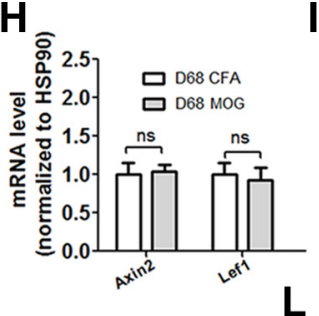

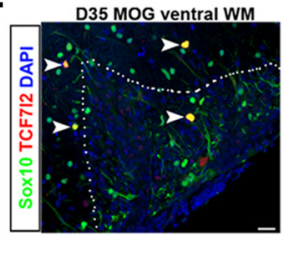

1

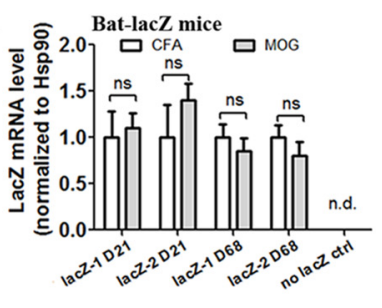

D42 MOG dorsal column D42 CFA

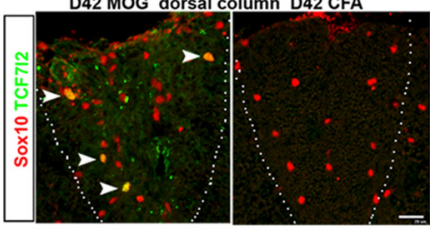

$\mathrm{J}$
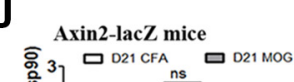
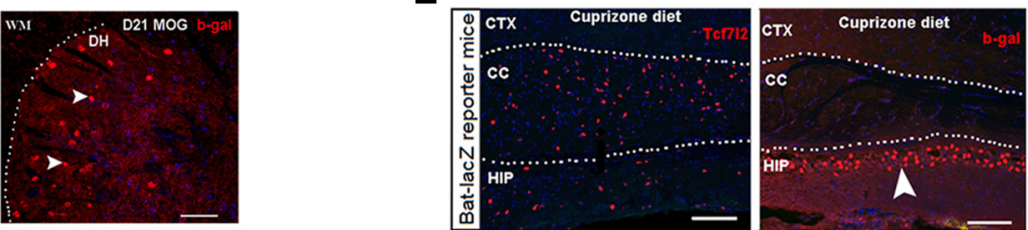

Figure 4. TCF7I2 expression is not associated with canonical Wnt signaling during developmental myelination nor remyelination. $A$, Representative confocal images of triple IHC of TCF7I2, Wnt reporter $\beta$-gal, and Sox10 in P1 spinal cord of Bat-LacZ mice. Arrowheads point to TCF7l2 ${ }^{+} / \mathrm{Sox}_{10}{ }^{+}$cells that are $\beta$-gal ${ }^{-}$. B, Quantification of TCF712 ${ }^{+} / \mathrm{Sox}_{10}{ }^{+}$cells and $\beta$-gal ${ }^{+} / \mathrm{TCF} 7 \mathrm{2}{ }^{+} /$ Sox $10^{+}$cells at different time points. $n=4$ at each time point of P1,P7,P10, and P14, except $n=3$ at P30. C, Percentage of $\beta$-gal ${ }^{+}$cells among different cell populations. $n=4$ at each time point of P1, P7, P10, and P14, except $n=3$ at P30.D, Representative confocal images showing that TCF712 ${ }^{+}$cells (arrows) are $\beta$-gal ${ }^{-}$(arrowheads) in the corpus callosum at P7. E, Quantification of Tcf7/2 mRNA expression in $M_{30}$-55-peptide induced EAE and CFA control by RT-qPCR at day 21 (D21) and D68 after EAE. F, Representative confocal images of double IHC of TCF712 and Sox 10 in the WM of D35 MOG (left) and in the dorsal columns of D42 MOG (middle) and CFA (right). Arrowheads point to double-positive cells. Dotted lines in $\boldsymbol{F}$ delineate areas of inflammatory infiltration in ventral WM (left image) and dorsal columns (right two images) of spinal cord. G, H, mRNA levels of Wnt target genes in MOG and CFA of D21 and D68 spinal cord. I, Quantification of LacZ mRNA by RT-qPCR in the spinal cord of D21 and D68 Bat-LacZ mice (2 primer sets LacZ-1 and LacZ-2 targeting different region of LacZ gene are used). Note that LacZ mRNA was not detected (n.d.) in nontransgene controls.J, Quantification of LaCZ and Wnt target genes in D21 CFA and MOG spinal cord of Wnt reporter Axin2-LaCZ mice. $K$, Representative confocal images of $\beta$-gal immunostaining at D21 after EAE of Bat-LacZ mice. Arrowheads point to $\beta$-gal ${ }^{+}$neurons in the dorsal horn (DH). L, Representative confocal images of TCF7l2 (left) and $\beta$-gal (right) immunostaining in the forebrain of Bat-LacZ mice that had been maintained on cuprizone diet for 6 weeks. Note that many TCF7l2 ${ }^{+}$cells are present in the corpus callosum (CC), but no $\beta$-gal ${ }^{+}$cells are present in the CC. Arrowhead points to $\beta$-gal ${ }^{+}$cells in the hippocampus (HIP), a known area with Wnt signaling activation. CTX, Cortex. All data are collected from the spinal cord of Bat-LacZ Wnt reporter mice, except $K$ is from the spinal cord of Axin2-LacZ Wnt reporter mice. Two-tailed Student's t test, ${ }^{*} p<0.05,{ }^{* *} p<0.01,{ }^{* * *} p<0.001$. ns, Not significant. $n=4$ in each group at D21, $n=5$ at D68. Scale bars: $A, D$, $F, 10 \mu \mathrm{m} ; K, 50 \mu \mathrm{m} ; L, 100 \mu \mathrm{m}$.

was ablated successfully in $P l p-C r e E R^{T 2}, T c f 7 l 2^{\mathrm{fl} / \mathrm{fl}}$ spinal cord $24 \mathrm{~h}$ after initial tamoxifen injection at P9 (Fig. 7A1), as indicated by the substantial diminution of TCF712 immunostaining signals (Fig. 7A3) and Tcf7l2 exon $1 \mathrm{mRNA}$ (Fig. $7 B$, the first bar graph set) in $P l p-C r e E R^{T 2}, T c f 7 l 2^{\mathrm{fl} / \mathrm{fl}}$ mutants. However, the expressions of the major myelin genes $P l p$ and Mbp, Sox10, and Olig2 and mature OL enzyme aspartoacylase (ASPA) were not altered during this "acute" short time window between Tcf7l2 deletion and analysis (Fig. $7 B$ ), suggesting that the myelin genes of $P l p$ and $M b p$ are not immediate target genes of TCF712 in OLs in vivo. Furthermore, the expression of Yin Yang 1 (YY1), a transcription factor that has been shown to promote OL differentiation and to suppress TCF712 expression (He et al., 2007), did not change (Fig. $7 B$, right). Consistently, the intensities and the patterns of $P l p$ and $M b p$ mRNAs in both forebrain (data not shown) and spinal cord (Fig. 7C) were similar in $P l p-C r e E R^{T 2}, T c f 7 l 2^{\mathrm{fl} / \mathrm{fl}}$ mice and littermate controls treated by the same tamoxifen paradigm. To evaluate the long-term effect of TCF712 deletion in differentiated OLs on myelin gene expression, we analyzed spinal cord tissue 1 week after TCF7l2 cKO in differentiated OLs (Fig. 7D). The expression of most myelin genes were not changed in $P l p-C r e E R^{T 2}, T c f 7 l 2^{\mathrm{fl} / \mathrm{fl}}$ mutants (Fig. 7E), nor was the density of $\mathrm{CC}^{+}{ }^{+}$differentiated OLs (Fig. 7F), indicating that TCF712 expression in differentiated OLs neither directly nor indirectly regulates the expression of major myelin genes. Of note, however, the expressions of MAG and Elovl1, an elongase required for synthesis of very long-chain fatty acids, were significantly downregulated when TCF712 was ablated conditionally in differentiated OLs at both $24 \mathrm{~h}$ and $7 \mathrm{~d}$ (Fig. 7G,H).

TCF712 regulates OL differentiation in a manner independent of Wnt/ $\beta$-catenin signaling

The Wnt effector TCF712 mediates the activity of canonical Wnt/ $\beta$-catenin signaling in Wnt-responsive cells, for example, in colorectal cancer cells (Anastas and Moon, 2013). In the absence of Wnt, the APC-containing destruction complex constitutively de- 
A $\operatorname{loxp} \quad \operatorname{loxP} T$ Tcf7l2fl/fl $\rightarrow-\exp >2 / 1$ 国-100 $\square \beta$-catenin binding domain $\square$ groucho binding domain DNA binding domain
B

Tamoxifen Analysis

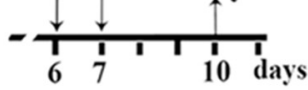

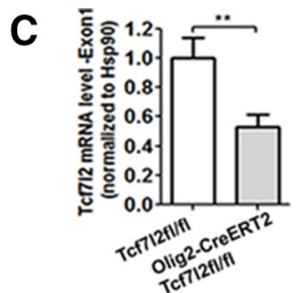
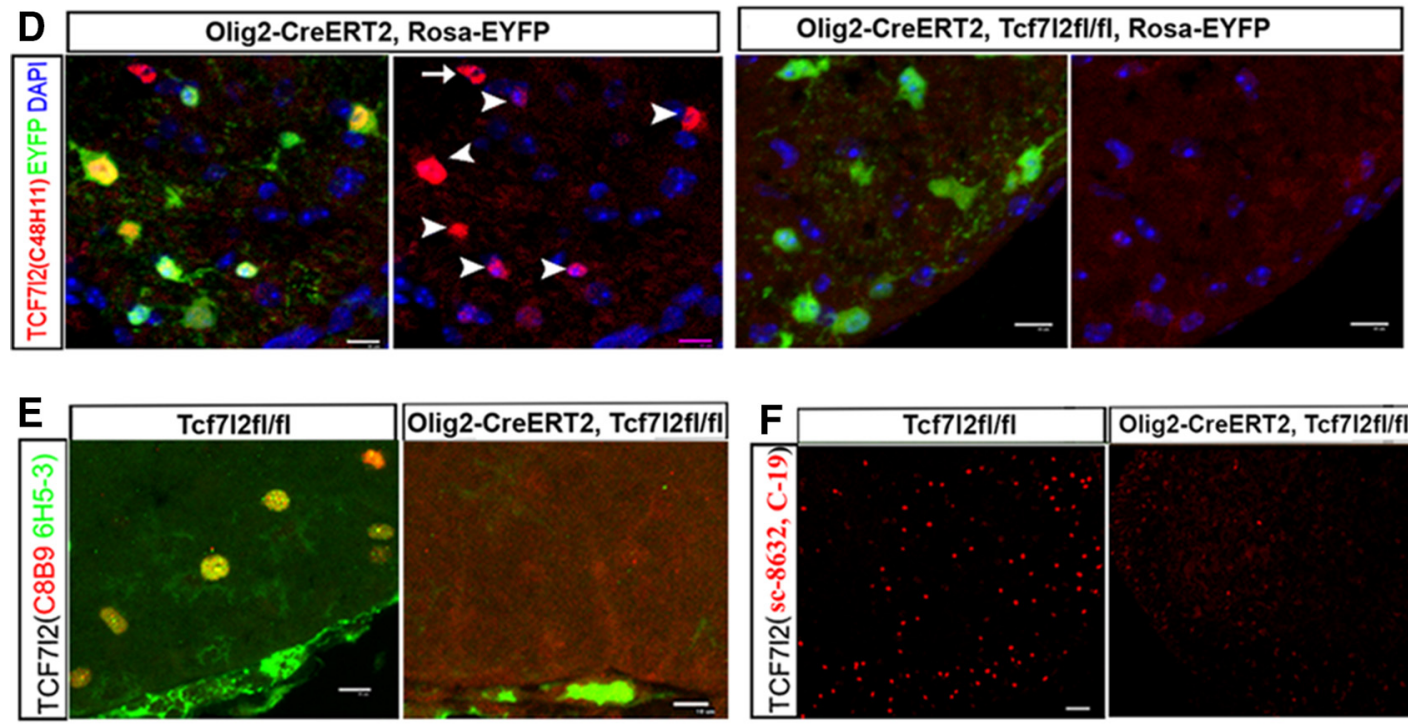

Olig2-CreERT2, Tcf7|2fl/fi

G
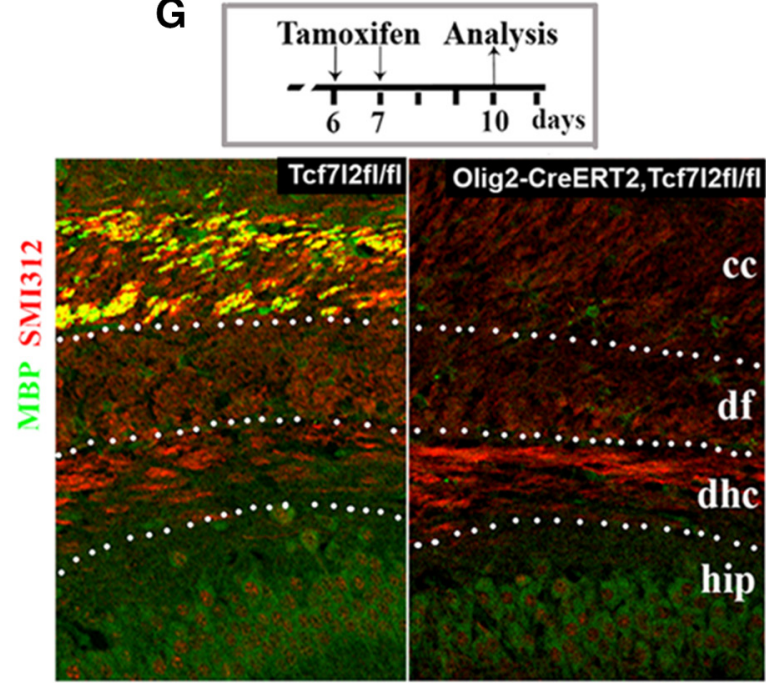

I

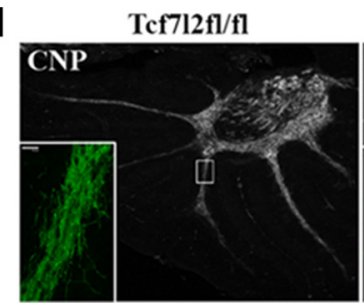

Olig2-CreERT2, Tcf7|2fl/fl

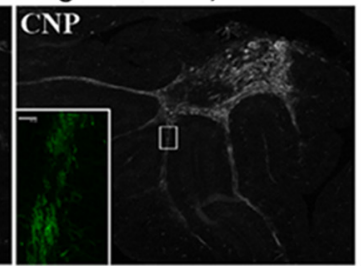

H

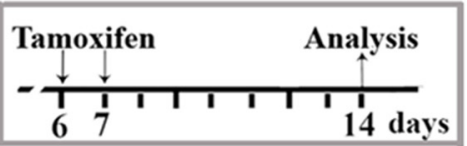

Tcf7|2fl/fl Olig2-CreERT2, Tcf7l2fl/fl
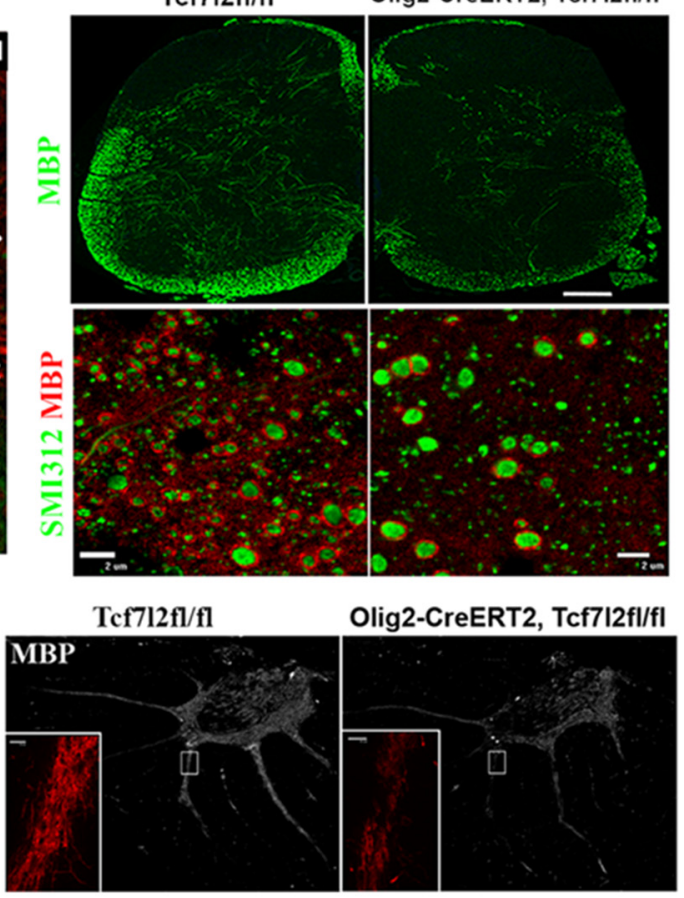

Figure 5. Conditional ablation of TCF7/2 results in hypomyelination. A, Structure of $T c f 7 / 2{ }^{\mathrm{fl} / f l}$ allele. $\boldsymbol{B}$, Experimental design for $\boldsymbol{C}-\boldsymbol{F}$. C, Quantification of mRNA level of $T c f 7 / 2$ exon 1 by RT-qPCR. $n=5$ in $T c f 7 / 2^{\mathrm{f} / f \mathrm{fl}}, n=3$ in Olig2-CreER ${ }^{T 2}, T c f 7 / 2^{\mathrm{fl} / f 1}$. Two-tailed Student's $t$ test, ${ }^{* *} p<0.01$. C, Western blot showing the ablation of the DNA-binding domain of TCF7l2. D-F, Representative confocal images of TCF7I2 immunostaining using antibodies against different regions of TCF712 (see Materials and Methods). Arrowheads and arrow in $D$ point to EYFP ${ }^{+} /$TCF7I2 $^{+}$and EYFP ${ }^{-} /$ $\mathrm{TCF}_{12}{ }^{+}$cells, respectively, in Olig2-CreER ${ }^{T 2}$, Rosa-EYFP mice. G, Experimental design (top) and double IHC of MBP and pan-axonal marker SMI312 in the forebrain (bottom). Hip, Hippocampus; dhc, dorsal hippocampal commissure; df, dorsal fornix, cc, corpus callosum. $\boldsymbol{H}$, Experimental design (top) for $\boldsymbol{H}$ and $\boldsymbol{I}$ and representative confocal images of MBP IHC at low magnification (middle) and of double IHC of MBP and SMI312 in the spinal cord dorsal columns at higher magnification (bottom). $I$, Representative confocal images of CNP and MBP in the cerebellum. Small boxed areas are shown at higher magnification at the left bottom corner of each panel. Scale bars: $\boldsymbol{D}, \boldsymbol{E}, 10 \mu \mathrm{m} ; \boldsymbol{G}, 20 \mu \mathrm{m} ; \boldsymbol{F}$, middle in $\boldsymbol{H}, 50 \mu \mathrm{m}$; bottom in $\boldsymbol{H}, 2 \mu \mathrm{m} ; \boldsymbol{I}, 10 \mu \mathrm{m}$. 
A
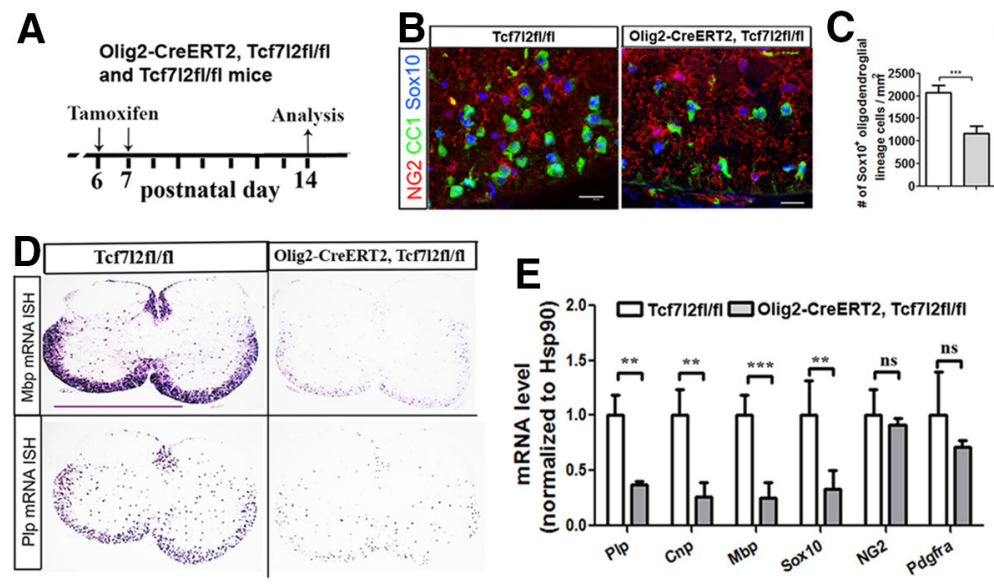

G

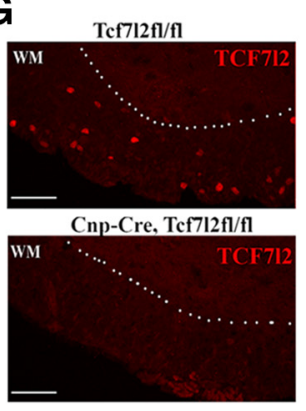

H

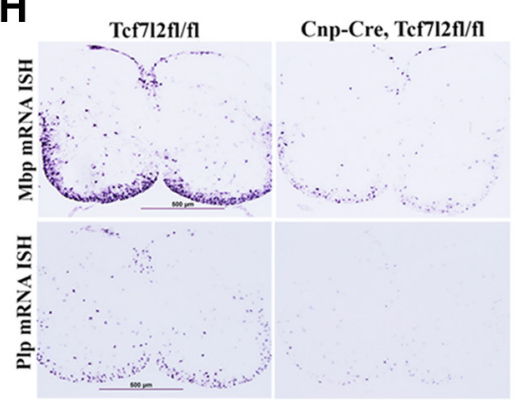

$\mathbf{F}$

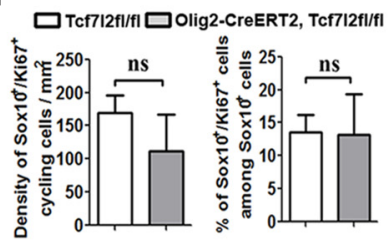

Figure 6. Conditional ablation of TCF712 by two different Cre drivers inhibits $0 \mathrm{~L}$ differentiation. $\boldsymbol{A}$, Experimental design for $\boldsymbol{B}-\boldsymbol{F}$. $\boldsymbol{B}, \boldsymbol{C}$, Representative confocal images of triple IHC of NG2, CC1, and Sox10 in the spinal cord (B) and quantification (C).D, mRNA ISH of PIp and Mbp in the spinal cord. $\boldsymbol{E}$, mRNA expression level of oligodendroglial genes quantified by RT-qPCR in the spinal cord. $\boldsymbol{F}$,

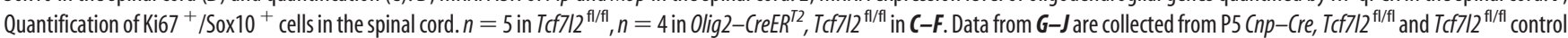
mice. G, IHC of TCF7I2 (antibody against DNA-binding domain) in the spinal cord. $\boldsymbol{H}, \mathrm{mRNA}$ ISH of Mbp and PIp in the spinal cord. I, RT-qPCR quantification of mRNA expression of $T c f 7 / 2$ exon 1 , the myelin genes Mbp, Plp, and Cnp, the OPC markers NG2 and PDGFR $\alpha$, and cell-cycle regulator Cyclin D1.J, Quantification of Sox $10^{+}$pan-oligodendroglial lineage cells, $C\left(1^{+} / S 0 x 10^{+}\right.$differentiated

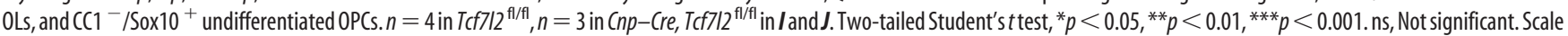
bars: $\boldsymbol{B}, 10 \mu \mathrm{m} ; \boldsymbol{D}, 1 \mathrm{~mm} ; \boldsymbol{G}, 50 \mu \mathrm{m} ; \boldsymbol{H}, 500 \mu \mathrm{m}$.

grades cytoplasmic $\beta$-catenin, preventing it from binding nuclear TCF7l2, whereas in the presence of Wnt, $\beta$-catenin accumulates in the cytoplasm and translocates into the nucleus, in which it binds TCF712 to activate the expression of immediate target genes in Wnt-responsive cells (Fig. 8A), for example, Axin2, Naked1, Notum, Lef1 (Lang et al., 2013), and Sp5 (Fig. 1A; Fancy et al., 2014). Therefore, the altered expression of these immediate target genes during TCF712 deletion provides a reliable readout by which to evaluate the involvement of oligodendroglial TCF712 in $\mathrm{Wnt} / \beta$-catenin signaling.

We used Olig2-CreER ${ }^{T 2}$, Tcf7l2 ${ }^{\mathrm{f} / \mathrm{fl}}$ transgenic mice to conditionally ablate TCF712 predominantly in OPCs at P6 and analyzed gene expression $24 \mathrm{~h}$ later (Fig. $8 \mathrm{~B}$, top of experimental design). In this acute cKO system, we observed significant decreases in Plp, Mbp, and Sox10 mRNAs (Fig. 8B, left part of bottom), again suggesting a positive role of TCF712 in the transition of OPCs into myelin gene-expressing OLs. However, the mRNA expressions of the Wnt target genes Axin2 and $S p 5$, which are upregulated significantly in APC cKO oligodendroglial lineage cells (Fig. 1A; Lang et al., 2013; Fancy et al., 2014), were unchanged in Olig2-CreER $R^{T 2}, T c f 72^{\mathrm{fl} / \mathrm{fl}}$ mutants (Fig. $8 B$, right part of bottom). Furthermore, we also showed that the Wnt target genes Axin2, Naked1, Notum, Sp5, and Lef1 were all unchanged at $4 \mathrm{~d}$ after TCF712 deletion in Olig2-CreER ${ }^{T 2}$, Tcf7l2 ${ }^{\mathrm{fl} / \mathrm{fl}}$ mutants (Fig. $8 C$ ), suggesting that TCF7l2 in oligodendroglial lineage cells does not mediate the activity of Wnt $/ \beta$-catenin signaling. We further showed that another related member of the TCF/LEF family, TCF7l1, was not upregulated at the mRNA level (Fig. 8C, rightmost set of bar graph) or protein level (data not shown) to compensate for TCF7l2 deletion.

Does TCF7l2 disruption in $\mathrm{Plp}^{+}$differentiated OLs perturb the $\mathrm{Wnt} / \beta$-catenin activity in these OLs, as indicated in a previous study (Tawk et al., 2011)? To address this important question, we conditionally ablated Tcf7l2 in $P l p^{+}$differentiated OLs using $P l p-C r e E R^{T 2}$, Tcf7l $2^{\mathrm{fl} / \mathrm{fl}}$ transgenic mice by tamoxifen treatment (Fig. $8 D$, top; for TCF7l2 deletion in differentiated OLs, see Fig. 7A1-A3). In this TCF7l2 cKO system, we did not observe changes in mRNA expression of the Wnt target genes Axin2 and Naked1 (Fig. 8D, left half of bottom). Surprisingly, however, expression of mRNAs encoding BMP4, a ligand for BMP/SMAD signaling, and inhibitor of DNA binding 3 (Id3), a direct target of BMP/SMAD signaling, were upregulated significantly at $24 \mathrm{~h}$ after TCF7l2 ablation in $P l p-C r e E R^{T 2}, T c f 7 l^{\mathrm{fl} / \mathrm{fl}}$ mice compared with $T c f 7 l 2^{\mathrm{f} / \mathrm{fl}}$ littermate controls (Fig. $8 D$, right half of bottom). These data suggest that TCF712 does not transcriptionally mediate upstream Wnt $/ \beta$-catenin signaling in OLs and that BMP signaling may be an immediate target of Wnt effector TCF7l2 in the oligodendroglial lineage.

It was reported previously that TCF712 was colabeled with Wnt reporter $\beta$-gal in neonatal Bat-LacZ mice (Fancy et al., 2009; Fig. $4 A-C$ ), suggesting that TCF7l2 may mediate $\mathrm{Wnt} / \beta$-catenin signaling in a temporally specific manner, i.e., transiently in neonatal oligodendroglial lineage cells before active OL differentiation and myelination. We found that tamoxifen had a toxic effect 
Table 2. Significantly downregulated genes in the spinal cord of TCF7l2 cKO (Olig2$C$ reER $\left.R^{T 2}, T c f 7 / 2^{f / / f l}\right)$ compared with $T c f 7 / 2^{f / / f 1}$ controls from gene array analysis

\begin{tabular}{|c|c|}
\hline Gene symbol & Fold down \\
\hline Opalin & 3.5 \\
\hline Casr & 3.0 \\
\hline 9630013A20Rik & 2.7 \\
\hline Alox5 & 2.7 \\
\hline Tmem141 & 2.5 \\
\hline Gm3088 & 2.4 \\
\hline Erbb3 & 2.4 \\
\hline Mag & 2.3 \\
\hline Tmem2 & 2.3 \\
\hline Gm19439 & 2.2 \\
\hline Parvb & 2.1 \\
\hline Mobp & 2.1 \\
\hline Trim59 & 2.1 \\
\hline Gm98 & 2.0 \\
\hline Mog & 2.0 \\
\hline $\mathrm{Fa} 2 \mathrm{~h}$ & 2.0 \\
\hline Adamts4 & 2.0 \\
\hline Cenyl1 & 2.0 \\
\hline Man1a & 2.0 \\
\hline Tmem88b & 2.0 \\
\hline Plekha1 & 1.9 \\
\hline II23a & 1.9 \\
\hline Syt12 & 1.9 \\
\hline Aspa & 1.9 \\
\hline Plekhh1 & 1.9 \\
\hline Gsn & 1.9 \\
\hline 1700047M11Rik & 1.9 \\
\hline Cldn11 & 1.9 \\
\hline Secisbp2l & 1.9 \\
\hline Peli1 & 1.9 \\
\hline 0tud7b & 1.9 \\
\hline SIc12a2 & 1.8 \\
\hline 2810468N07Rik & 1.8 \\
\hline Gjc2 & 1.8 \\
\hline Anln & 1.8 \\
\hline Plekhg3 & 1.8 \\
\hline Ugt8a & 1.8 \\
\hline Plat & 1.8 \\
\hline Sh3gl3 & 1.8 \\
\hline Tmem123 & 1.8 \\
\hline Jam3 & 1.8 \\
\hline Rasgef1b & 1.8 \\
\hline C030030A07Rik & 1.7 \\
\hline Ldlrap1 & 1.7 \\
\hline Stxbp3a & 1.7 \\
\hline Snx30 & 1.3 \\
\hline Taf10 llk & 1.3 \\
\hline Lgi3 & 1.3 \\
\hline Pip4k2a & 1.3 \\
\hline LOC100861831 & 1.3 \\
\hline Ipo13 & 1.3 \\
\hline Fbx08 & 1.3 \\
\hline Degs1 & 1.3 \\
\hline Stk39 & 1.3 \\
\hline Plekhb1 & 1.3 \\
\hline Ube2g1 & 1.3 \\
\hline Pop4 & 1.3 \\
\hline Tbc1d5 & 1.3 \\
\hline Pi4kb & 1.3 \\
\hline Me1 & 1.2 \\
\hline Mtap7 & 1.7 \\
\hline Gltp & 1.7 \\
\hline Elovl1 & 1.7 \\
\hline Tprn & 1.7 \\
\hline
\end{tabular}

Table 2. Continued

\begin{tabular}{|c|c|}
\hline Gene symbol & Fold down \\
\hline Cnp & 1.7 \\
\hline Dhcr24 & 1.7 \\
\hline Lass2 & 1.7 \\
\hline Rhog & 1.7 \\
\hline Ninj2 & 1.7 \\
\hline Olig2 & 1.7 \\
\hline Rap1a & 1.7 \\
\hline Hspa2 & 1.7 \\
\hline Tspan15 & 1.7 \\
\hline Syde2 & 1.6 \\
\hline Zdhhc9 & 1.6 \\
\hline Sema4d & 1.6 \\
\hline Tmem125 & 1.6 \\
\hline Hapln2 & 1.6 \\
\hline Ppp1r14a & 1.6 \\
\hline 1500015L24Rik & 1.6 \\
\hline Tspan2 & 1.6 \\
\hline Klhl2 & 1.6 \\
\hline Arhgef10 & 1.6 \\
\hline Tns3 & 1.6 \\
\hline Dock10 & 1.6 \\
\hline Tmem182 & 1.6 \\
\hline Piga & 1.6 \\
\hline Plekhg1 & 1.6 \\
\hline Strn & 1.6 \\
\hline Carhsp1 & 1.6 \\
\hline Atp8b1 & 1.6 \\
\hline Idh1 & 1.6 \\
\hline Tppp & 1.6 \\
\hline Adipor2 & 1.6 \\
\hline Nfasc & 1.6 \\
\hline Il1rap & 1.6 \\
\hline Ddc & 1.5 \\
\hline Gss & 1.5 \\
\hline Mal & 1.5 \\
\hline Gab1 & 1.5 \\
\hline Rab33a & 1.5 \\
\hline Kndc1 & 1.5 \\
\hline Stx2 & 1.5 \\
\hline Gramd3 & 1.5 \\
\hline Sorbs3 & 1.5 \\
\hline Foxn3 & 1.2 \\
\hline Hipk2 & 1.2 \\
\hline Erf & 1.2 \\
\hline Atp6v1g1 & 1.2 \\
\hline D15Ertd621e & 1.2 \\
\hline AW549877 & 1.2 \\
\hline Lpar3 & 1.2 \\
\hline Ltv1 & 1.2 \\
\hline Aatk & 1.2 \\
\hline Nudt4 & 1.2 \\
\hline Pim3 & 1.2 \\
\hline Nkain2 & 1.2 \\
\hline Acsl3 Utp14b & 1.2 \\
\hline Csrp1 & 1.2 \\
\hline Txndc16 & 1.2 \\
\hline St18 & 1.5 \\
\hline Mcam & 1.5 \\
\hline Nkx6-2 & 1.5 \\
\hline Dbndd2 & 1.5 \\
\hline Tmem63a & 1.5 \\
\hline 6330503K22Rik & 1.5 \\
\hline Klhl4 & 1.5 \\
\hline$S c 5 d$ & 1.5 \\
\hline Snx18 & 1.5 \\
\hline
\end{tabular}


Table 2. Continued

\begin{tabular}{|c|c|}
\hline Gene symbol & Fold down \\
\hline Fbxo32 & 1.5 \\
\hline Ppp1r16b & 1.5 \\
\hline Dusp15 & 1.5 \\
\hline Ypel2 & 1.5 \\
\hline Rffl & 1.5 \\
\hline Smad7 & 1.5 \\
\hline Kif19a & 1.5 \\
\hline G2e3 & 1.5 \\
\hline Rcbtb1 & 1.5 \\
\hline Apod & 1.5 \\
\hline Enpp2 & 1.4 \\
\hline Sox2 & 1.4 \\
\hline Сур51 & 1.4 \\
\hline Ctnnal1 & 1.4 \\
\hline Npc1 & 1.4 \\
\hline Ephb1 & 1.4 \\
\hline Pex5I & 1.4 \\
\hline Fmnl2 & 1.4 \\
\hline II12rb1 & 1.4 \\
\hline Hhip & 1.4 \\
\hline Gm19500 & 1.4 \\
\hline SIc44a1 & 1.4 \\
\hline Sox10 & 1.4 \\
\hline Map4k4 & 1.4 \\
\hline Kat2b & 1.4 \\
\hline Reep3 & 1.4 \\
\hline Ick & 1.4 \\
\hline Rab31 & 1.4 \\
\hline Enpp4 & 1.4 \\
\hline Zfp536 & 1.4 \\
\hline Nde1 & 1.4 \\
\hline Ankrd13a & 1.4 \\
\hline Fntb LOC639541 & 1.4 \\
\hline Ado & 1.4 \\
\hline Acy3 & 1.4 \\
\hline Chmp1b & 1.4 \\
\hline Ctnna1 & 1.2 \\
\hline Aplp1 & 1.2 \\
\hline Lamp1 & 1.2 \\
\hline Ktn1 & 1.2 \\
\hline Creb5 & 1.2 \\
\hline Prrg1 & 1.2 \\
\hline Eps15 & 1.2 \\
\hline Ankib1 & 1.2 \\
\hline Picalm & 1.2 \\
\hline Mmgt1 & 1.2 \\
\hline Cap1 & 1.2 \\
\hline Dock9 & 1.2 \\
\hline Fth1 & 1.2 \\
\hline Polr1d & 1.2 \\
\hline Fkbp1a & 1.2 \\
\hline Sirt2 & 1.4 \\
\hline Creb312 & 1.4 \\
\hline Ptpn11 & 1.4 \\
\hline Prickle1 & 1.4 \\
\hline Rtkn & 1.4 \\
\hline Ptpdc1 & 1.4 \\
\hline Npat & 1.4 \\
\hline Cpd & 1.4 \\
\hline Fgfr2 & 1.4 \\
\hline Cdk19 & 1.4 \\
\hline Acsl1 & 1.4 \\
\hline Bace1 & 1.4 \\
\hline Mbp & 1.4 \\
\hline \multirow[t]{2}{*}{ Sypl } & 1.4 \\
\hline & (Tabel Continues) \\
\hline
\end{tabular}

Table 2. Continued

\begin{tabular}{|c|c|}
\hline Gene symbol & Fold down \\
\hline Dram2 & 1.4 \\
\hline Fam108b & 1.4 \\
\hline Gm11492 & 1.4 \\
\hline Eif2c3 & 1.4 \\
\hline Npc2 & 1.4 \\
\hline Bin1 & 1.4 \\
\hline Gjb1 & 1.3 \\
\hline Сур3а13 & 1.3 \\
\hline Rnf13 & 1.3 \\
\hline Setd8 & 1.3 \\
\hline Nkain1 & 1.3 \\
\hline Evi2a Evi2b & 1.3 \\
\hline Ankrd49 & 1.3 \\
\hline Smurf1 & 1.3 \\
\hline Erbb2ip & 1.3 \\
\hline Phactr4 & 1.3 \\
\hline Tmem163 & 1.3 \\
\hline Mospd2 & 1.3 \\
\hline Qk & 1.3 \\
\hline 2810008M24Rik & 1.3 \\
\hline Entpd5 & 1.3 \\
\hline Rock1 & 1.3 \\
\hline Ralgds & 1.3 \\
\hline +Papss1 & 1.3 \\
\hline Gm19897 & 1.3 \\
\hline Myo6 & 1.3 \\
\hline Mtmr2 & 1.3 \\
\hline Rap2a & 1.3 \\
\hline Arap2 & 1.3 \\
\hline Snap23 & 1.3 \\
\hline Twf1 Gm4887 & 1.3 \\
\hline Tbc1d14 & 1.2 \\
\hline Srd5a1 & 1.2 \\
\hline Lrrn1 & 1.2 \\
\hline Slc22a23 & 1.2 \\
\hline Dhrs7 & 1.2 \\
\hline $\mathrm{Gclm}$ & 1.2 \\
\hline Rhbdl2 & 1.2 \\
\hline Ncor2 & 1.2 \\
\hline Kif5b & 1.2 \\
\hline Rhoa & 1.2 \\
\hline Mtmr6 & 1.2 \\
\hline Gm428 & 1.2 \\
\hline Add1 & 1.2 \\
\hline Plp1 & 1.2 \\
\hline Frmd4a & 1.2 \\
\hline
\end{tabular}

TCF7I2 was conditionally ablated in mice by tamoxifen injection at P6 and P7 (1 injection per day), and spinal cord tissue was harvested on P14. $n=4$ in each group, $p<0.05$ with false discovery rate correction. Only genes with a minimal downregulation of 1.2-fold in Olig2-CreER $R^{T 2}, T f f 72^{\mathrm{fl} / f 1}$ mice are shown here. Genes marked in bold are myelin genes or genes known to regulate $0 \mathrm{~L}$ differentiation.

on postnatal murine development if injected into neonatal and very early postnatal pups. To avoid this complication, we used tamoxifen-independent, constitutive Cnp-Cre to ablate TCF712 in the oligodendroglial lineage. In the spinal cord of Cnp-Cre, $T c f 72^{\mathrm{fl} / \mathrm{fl}}$ neonates at $\mathrm{P} 1$ when TCF712 starts to appear and OL differentiation has just begun, TCF7l2 mRNA (Fig. 8E, left part) and protein (data not shown) were significantly decreased compared with $T c f 72^{\mathrm{fl} / \mathrm{fl}}$ littermate controls. Consistent with a positive role of TCF712 in OL differentiation, the expression of the myelin gene Plp was significantly decreased compared with $T c f 7 l 2^{\mathrm{fl} / \mathrm{fl}}$ controls (Fig. 8E, middle part). However, the expression of the Wnt target gene Axin2 was comparable between CnpCre, $T c f 72^{\mathrm{fl} / \mathrm{fl}}$ mutant and controls (Fig. $8 E$, right part), suggesting that TCF712 does not mediate Wnt/ $\beta$-catenin signal- 
A1

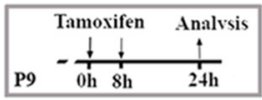

A2 PIP-CreERT2, Tcf712fl/f, Rosa-EYFP
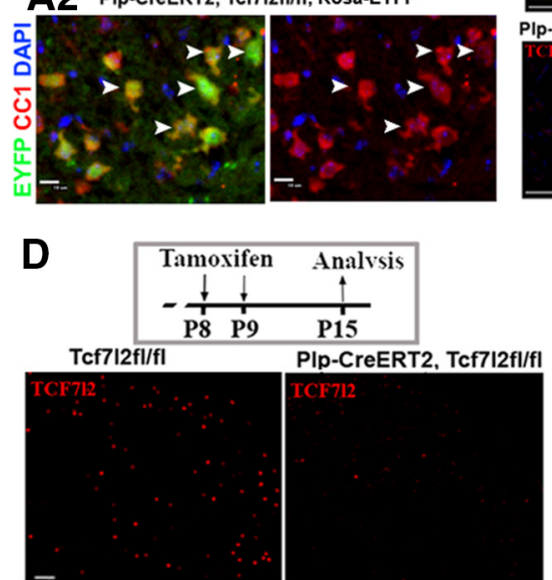

G $\frac{5}{0}$

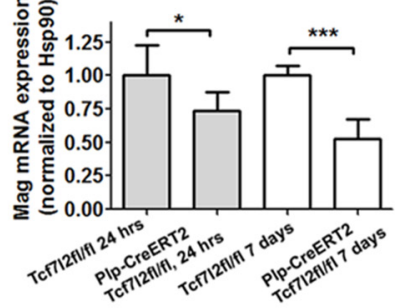

A3

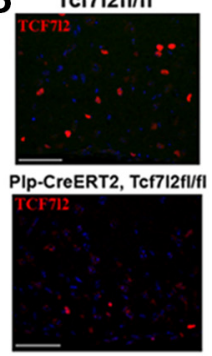

B

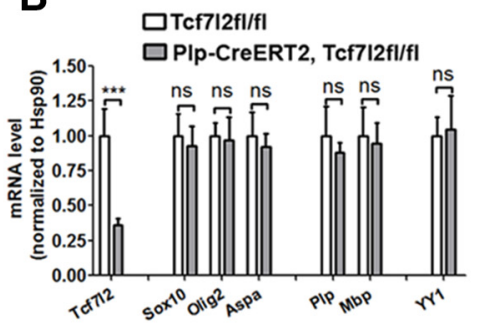

C

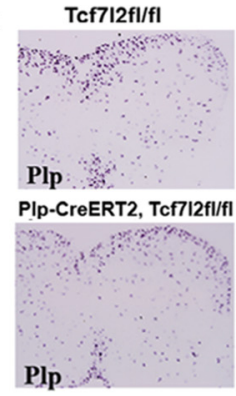

$\mathbf{E}$
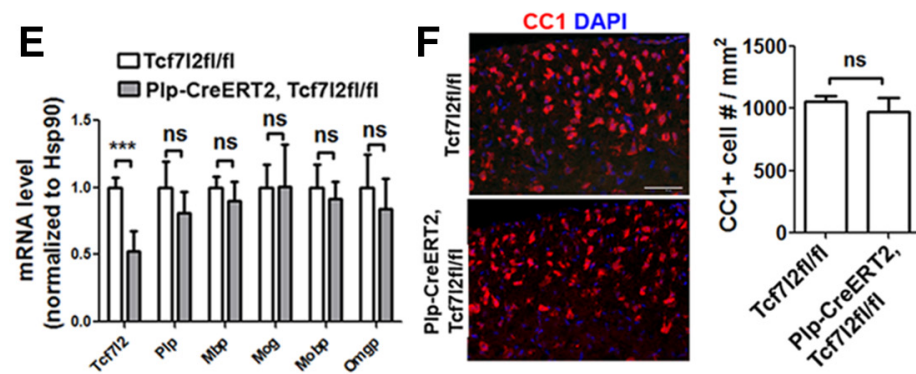

Figure 7. Conditional ablation of TCF7/2 in differentiated OLs does not affect myelin gene expression. $\boldsymbol{A}$, experimental design for $\boldsymbol{A} \mathbf{2}, \boldsymbol{A} \mathbf{3}, \boldsymbol{B}$, and $\boldsymbol{C}$. $\boldsymbol{A 2}$, Confocal images of immunostaining of EYFP and $C C 1$ in the spinal cord of PIp-CreER ${ }^{T 2}, T c f 7 / 22^{f / f f l}$, Rosa-EYFP reporter mice. Arrowheads point to EYFP ${ }^{+} / \mathrm{CC}^{+}{ }^{+}$differentiated OLs. A3, Confocal images of TCF7I2 in the spinal cord of $T c f 7 / 2^{\mathrm{fl} / 1 \mathrm{l}}$ (top) and $P / p-C r e E R^{T 2}, T c f 7 / 2^{\mathrm{fl} / f 1}$ (bottom) mice. B, mRNA levels of TCF7l2 exon 1, the oligodendroglial genes Sox 10, Olig2, and ASPA, the myelin genes $P / p$ and $M b p$, and the transcription factor YY1 in the spinal cord. $n=6$ in each group. $\boldsymbol{C}$, mRNA ISH of PIp in the spinal cord. $\boldsymbol{D}$, Experimental design (top) for $\boldsymbol{E}$ and $\boldsymbol{F}$ and confocal images of TCF7l2 IHC (bottom). $\boldsymbol{E}$, Gene expression in the spinal cord quantified by RT-qPCR. $n=5$ in $T c f 7 / 2^{f / f / f l}, n=5$ in Plp-CreER ${ }^{T 2}, T c f 7 / 2^{f / f / 1}$. Omgp, Oligodendrocyte myelin glycoprotein. $F$, Representative confocal images of $C C 1$ IHC in the spinal cord and quantification. $\mathbf{G}, \boldsymbol{H}, \mathrm{RT}-\mathrm{qPCR}$ quantification of MAG $(\boldsymbol{G})$ and Elovl1 $(\boldsymbol{H})$ in the spinal cord of $P C E, T c f 7 / 2^{\mathrm{fl} / \mathrm{fl}}$ and $T c f 7 / 2^{\mathrm{fl} / \mathrm{fl}}$ littermates at both $24 \mathrm{~h}$ and $7 \mathrm{~d}$ after TCf $7 / 2$ conditional ablation. Two-tailed Student's $t$ test, ${ }^{*} p<0.05,{ }^{* *} p<0.01,{ }^{* * *} p<0.001$. Scale bars: $A 2,10 \mu \mathrm{m} ;$ all others, $50 \mu \mathrm{m}$.

ing in neonatal oligodendroglial lineage cells. Interestingly, BMP4 expression and BMP/SMAD signaling targets Id 1, Id2, Id3, and Id 4 were upregulated significantly in Cnp-Cre, Tcf $7 / 22^{\mathrm{fl} / \mathrm{f}}$ (Fig. $8 F)$ at $\mathrm{P} 1$ compared with littermate controls, consistent with the data from $P l p-C r e E R^{T 2}, T c f 7 l 2^{\mathrm{fl} / \mathrm{f}}$ mutants (Fig. $8 D$, right half of bottom). Western blot confirmed the upregulation of BMP4 and also showed increased levels of phosphorylated-SMAD1/5 (Ser463/465), an active form of Smad1/5 required for BMP signaling activation, and comparable levels of Wnt target gene Axin2 at P1 (Fig. $8 G$ ). Collectively, these data suggest that TCF712 does not play a role in mediating $\mathrm{Wnt} / \beta$-catenin signaling but, instead, represses BMP/SMAD signaling in neonatal and postnatal oligodendroglial lineage cells.

The nonperturbation of Wnt signaling in TCF7l2 cKO mutants was further confirmed by analyzing tamoxifen-independent CnpCre, $T c f 7 l 2^{\mathrm{fl} / \mathrm{fl}} \mathrm{cKO}$ mutants at P5 when substantial OL differentiation occurs, evidenced by comparable levels of Wnt target gene expression between $\mathrm{cKO}$ and controls (Fig. $8 \mathrm{H}$ ). We further used gene microarray to screen for genes with altered expression in the TCF7l2 cKO of Olig2-CreER ${ }^{T 2}, T c f 7 l 2^{\mathrm{fl} / \mathrm{fl}}$ mutants (Table 2). We reasoned that, if TCF712 regulates OL differentiation through mediating $\mathrm{Wnt} / \beta$-catenin signaling activity, the genes of well known Wnt targets and potential candidates that are upregulated in APC cKO of Olig2-CreER ${ }^{T 2}, A p c^{\mathrm{fl} / \mathrm{fl}}$ mutants (Table 1) will be significantly downregulated in TCF712 cKO. However, the results showed that none of the upregulated genes in APC cKO (Table 1) appeared in the downregulated gene list derived from TCF712 cKO microarray analysis (Table 2).

$\beta$-Catenin is a required molecule to mediate canonical Wnt/ $\beta$-catenin signaling in Wnt-responsive cells. We had reported previously that $\beta$-catenin $\mathrm{CKO}$ did not affect the differentiation of neonatal and postnatal OLs (Lang et al., 2013) and now show that cKO of $\beta$-catenin (gene symbol, Ctnnb1) driven by Olig2-Cre$E R^{T 2}$ (Fig. 8I, top, and left part of bottom) did not affect the expression of Wnt target Axin2 (Fig. 8I, right part of bottom), nor of TCF712 expression (data not shown). Consistently, Wnt target gene Axin2 mRNA was barely detectable by mRNA ISH in TCF7l2 ${ }^{+}$OLs in the spinal cord (Fig. 1I). As a positive control, Axin 2 mRNA was observed readily in $\mathrm{LEF}^{+}{ }^{+}$but not $\mathrm{TCF} 72^{+}$ oligodendroglia in APC cKO spinal cord of Olig2-CreER ${ }^{T 2}$, $A p c^{\mathrm{fl} / \mathrm{fl}}$ mutants (Fig. $1 \mathrm{~J}$ ). ISH data indicate that TCF712 does not mediate $\mathrm{Wnt} / \beta$-catenin activation in OLs under either physiological or Wnt genetic activated (APC cKO) conditions.

Together, our in vivo experimental data demonstrate that TCF712 positively regulates neonatal and postnatal OL differentiation and that this regulation does not involve the role of Wnt/ $\beta$-catenin signaling, weakening the previous hypothesis that TCF712, through Wnt/ $\beta$-catenin signaling activation, plays an 
A
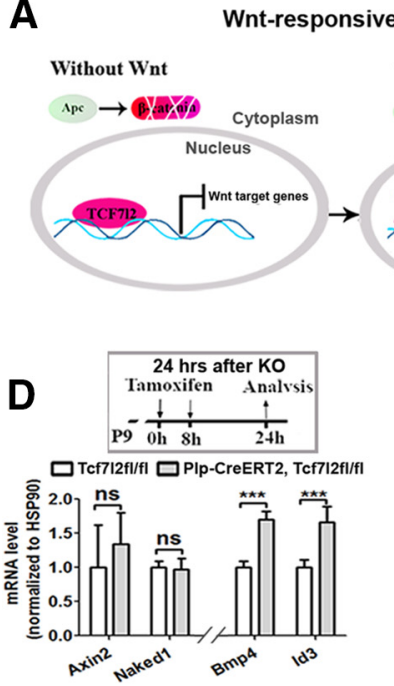

B

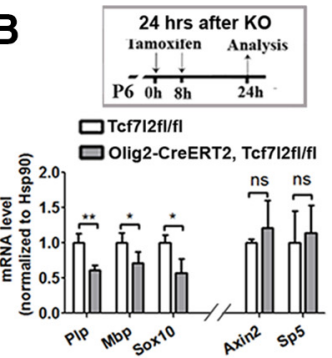

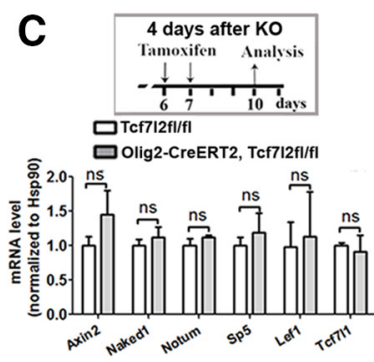

E $_{\square \text { Tef7l2f/fl spinal cord }}^{\square \text { Cnp-Cre, Tef7/2ff/fl }}$

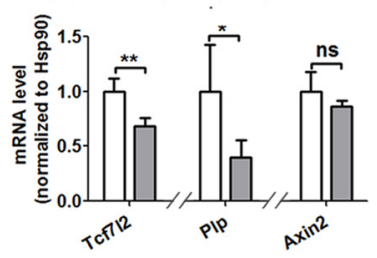

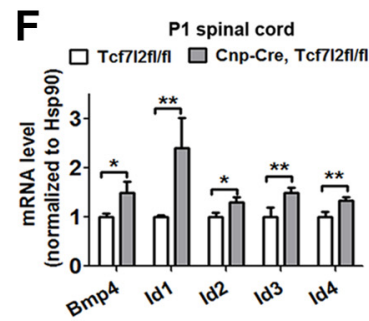

G
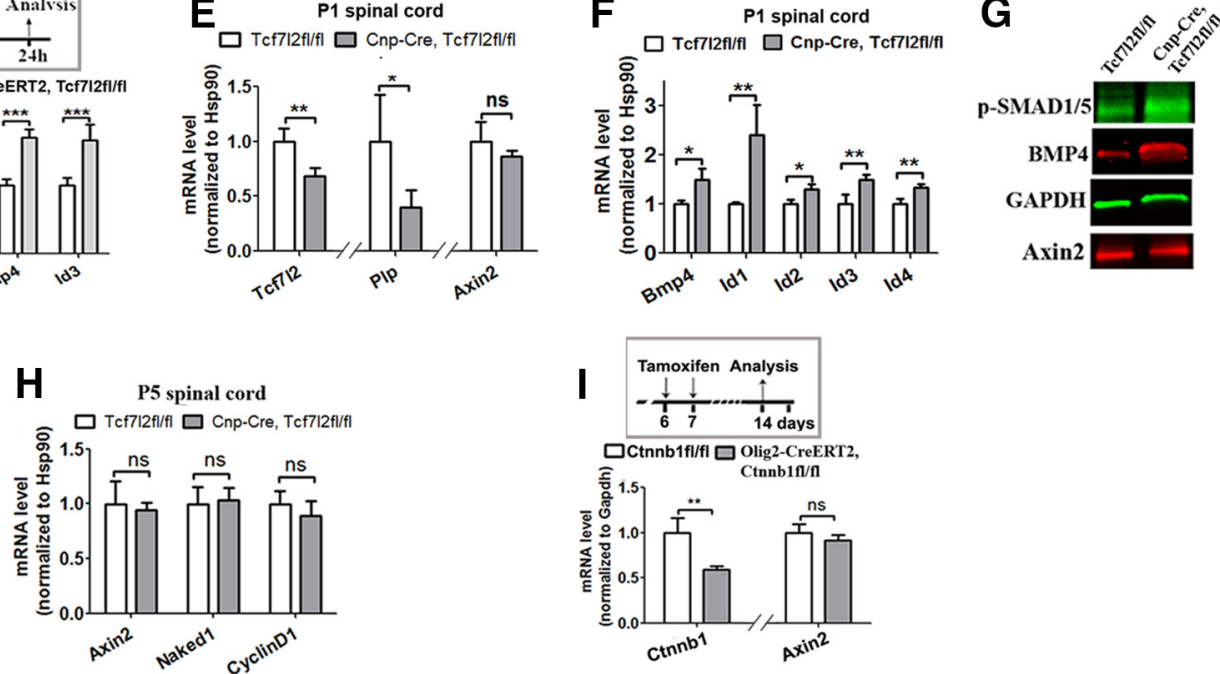

Figure 8. Canonical Wnt signaling activity is not perturbed in the TCF7I2 CKO mutants driven by different Cre promoters at different time points. A, Schematic diagram depicting the role of Wnt negative regulator APC, $\beta$-catenin, TCF712, and Wnt target gene expression in Wnt-responsive cells. The binding of $\beta$-catenin to TCF712 in the presence of Wnt activation switches TCF712 from a transcriptional repressor to an activator. Gray circled area depicts the nucleus. B, Quantification of oligodendroglial genes and Wnt target genes in the spinal cord of 0 lig2-CreER ${ }^{T 2}$, TCf7/2 ${ }^{\mathrm{f} / 1 / 1}(n=$ 4) and $T C f 7 / 2^{f / / f l}(n=5)$ controls at $24 \mathrm{~h}$ after conditional ablation of TCF712 in OPCS. C, Quantification of Wnt target genes and other members of Wnt effector LEF1 and TCF711 in the spinal cord of Olig2-CreER ${ }^{T 2}, T c f 7 / 2^{\mathrm{f} / f \mathrm{fl}}(n=4)$ and $T c f 72^{\mathrm{f} / / f 1}(n=4)$ controls at $4 \mathrm{~d}$ conditional ablation of TCF712 in OPCs. D, RT-qPCR quantification of the Wnt target genes BMP4 and Id3 in the spinal cord of $P \mid p-C r e E R^{T 2}, T c f 7 / 2^{f / / f l}$ and $T c f 7 / 2^{f / / f l}$ controls at $24 \mathrm{~h}$ after conditional ablation of TCF7/2 in Plp ${ }^{+} 0 L s . n=5$ in each group. $E$, The level of gene expression quantified by RT-qPCR in the spinal cord

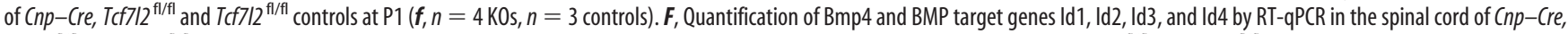
$T c f 7 / 2^{f / f / f l}$ and $T c f 7 / 2^{f / f / 1}$ controls at P1 $\left(\boldsymbol{f}, n=4 \mathrm{KOs}, n=3\right.$ controls). G, Western blot of spinal cord protein extracts from P1 Cnp-Cre, Tcf7/2 ${ }^{\mathrm{fl} / \mathrm{fl}}$ and $T c f 7 / 2^{\mathrm{fl} / \mathrm{fl}}$ in $0 \mathrm{Ls}$ using antibodies against Axin2, BMP4, and phosphorylated SMAD1/5 at Ser463/467, the activated form of SMAD1/5 for BMP signaling activation. $\boldsymbol{H}$, mRNA levels of Wnt targets Axin2 and Naked1 and the cell-cycle regulator Cyclin D1 quantified by RT-qPCR from the $C n p-C r e, T f 7 / 2^{\mathrm{fl} / \mathrm{fl}}$ and $T f 712^{\mathrm{fl} / \mathrm{f}}$ spinal cords at P5 ( $n=4$ each group). $I$, Quantification of $\beta$-catenin gene (Ctnnb1) and Wnt target Axin2 in the spinal cord of Olig2-CreER ${ }^{T 2}$, Ctnnb $^{1 / / f f}(n=3)$ and $C$ tnnb $1^{f / f / f l}$ control $(n=4) 7 \mathrm{~d}$ after $\beta$-catenin cK0. Two-tailed Student's t test, applied to all, ${ }^{*} p<0.05,{ }^{* *} p<0.01,{ }^{* * *} p<0.001$. ns, Not significant.

inhibitory role in postnatal oligodendroglial differentiation. Our data also suggest that TCF712 positively regulates OL differentiation likely by suppressing BMP/SMAD signaling pathways in oligodendroglial lineage cells.

\section{TCF712 promotes OL differentiation during remyelination after myelin damage}

Previous studies proposed that TCF712 may inhibit OL differentiation during myelination (Fancy et al., 2009; Fancy et al., 2011; Pedre et al., 2011). However, no genetic data have thus far been available to support this hypothesis. We used the cuprizone demyelination/remyelination model to determine the role of TCF712 in remyelination. Analysis of the temporal dynamics of OPCs and OLs in the corpus callosum revealed that OL regeneration in this model occurred mainly between week 5 of cuprizone diet and week 2 after return to a normal diet (Fig. 9A). At the end of week 6 of cuprizone diet, there was robust reinduction of TCF712 in the corpus callosum, and TCF712 was downregulated by week 4 of recovery (Fig. 9B, red). TCF712 colabeled with Wnt negative regulator APC during and after remyelination (Fig. 9B, green).

Based on these temporal dynamics of OL differentiation and TCF712 reinduction, we decided to administer tamoxifen daily to 2-month-old Olig2-CreER $R^{T 2}, T c f 7 l 2^{\mathrm{fl} / \mathrm{fl}}$ mice and $T c f 7 l 2^{\mathrm{fl} / \mathrm{fl}}$ controls between weeks 5 and 6 of cuprizone diet and analyze the corpus callosum $10 \mathrm{~d}$ after the last injection (for experimental design, see Fig. 9C). Plp mRNA ISH demonstrated substantially fewer $\mathrm{Plp}^{+}$differentiated OLs in the corpus callosum of Olig2$C r e E R^{T 2}, T c f 7 l 2^{\mathrm{fl} / \mathrm{fl}}$ mice compared with $T c f 7 l 2^{\mathrm{fl} / \mathrm{fl}}$ controls (Fig. 9D). We also used IHC of CC1 (Fig. 9E) and NG2 to quantify OLs and OPCs, respectively, and found that the density of differentiated OLs in the corpus callosum was significantly lower in Olig2$C r e E R^{T 2}, T c f 7 l 2^{\mathrm{fl} / \mathrm{fl}}$ than that in $T c f 7 l 2^{\mathrm{fl} / \mathrm{fl}}$ control mice, whereas the density of OPCs was comparable between these two groups (Fig. 9F). These data suggest that Tcf7l2 reinduction promotes OL differentiation in the cuprizone-induced demyelination/remyelination model.

\section{Discussion}

There are several significant findings in this study: (1) in contrast to previous reports, TCF712 is upregulated transiently in postmitotic, newly differentiated OLs but not in OPCs; (2) TCF712 expression is not associated with the activation of canonical Wnt/ $\beta$-catenin signaling during developmental myelination and remyelination; (3) TCF712 is an intrinsic positive regulator of OL 

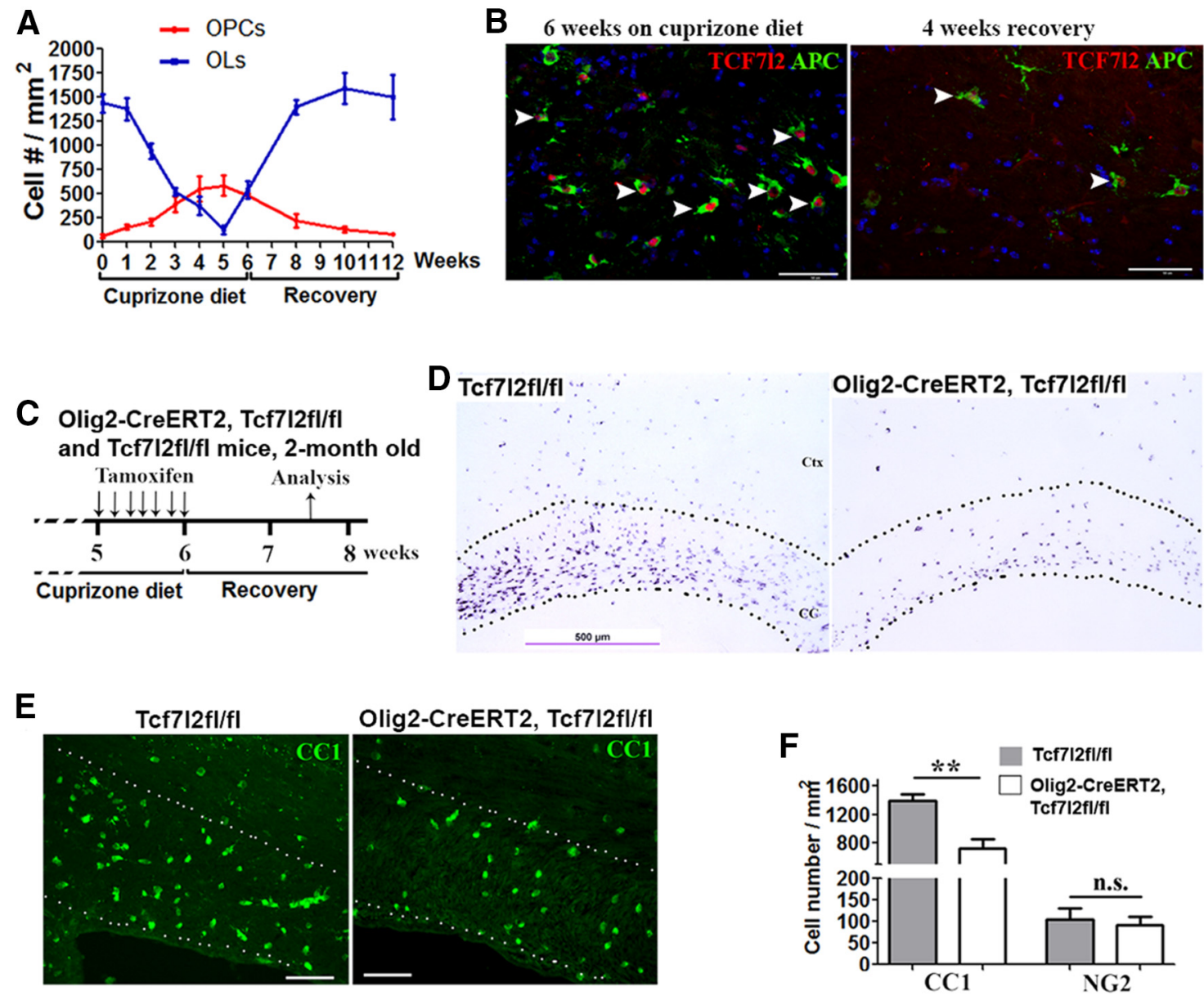

Figure 9. Conditional ablation of TCF7I2 inhibits $0 \mathrm{~L}$ differentiation in the cuprizone-induced demyelination model. $A$, Analysis of temporal dynamics of NG2 ${ }^{+} / \mathrm{S}$ ox $10^{+} 0 \mathrm{PCs}$ and $\mathrm{CC} 1{ }^{+} / \mathrm{S}$ ox $10^{+}$ OLs during cuprizone diet and return to normal diet (Recovery; $n=3$ at each time point). We focus on the corpus callosum at the approximate coronal location of bregma $-2.0 \mathrm{~mm}$. Two-month-old mice are used at the initiation of cuprizone diet. $\boldsymbol{B}$, Induction of TCF7I2 expression in $\mathrm{APC}^{+}$cells in the corpus callosum at week 6 on cuprizone diet (left) and at 4 weeks after return to normal diet (right). C, Experimental design of TCF7I2 CKO and analysis for $\boldsymbol{D}-\boldsymbol{F}$. D, PIp mRNA ISH of forebrains at $10 \mathrm{~d}$ after the last tamoxifen injection. CC, Corpus callosum; Ctx, cortex. $\boldsymbol{E}, \boldsymbol{F}$, Representative confocal images of $\mathrm{CC} 1 \mathrm{IHC}(\boldsymbol{E})$ and quantification of $\mathrm{CC} 1^{+} \mathrm{OLS}$ and NG2 ${ }^{+} \mathrm{OPCS}$ of corpus callosum $(\boldsymbol{F})$. Dotted areas in $E$ refer to the corpus callosum. $n=3$ for Olig2-CreER ${ }^{T 2}, T \mathrm{Cf} 7 \mathrm{I} 2^{\mathrm{fl} / \mathrm{fl}}, n=6 \mathrm{for}$ $T c f 7 / 2^{f / f / f l}$. Two-tailed Student's $t$ test, ${ }^{* *} p<0.01$. n.s., Not significant. Scale bars: $\boldsymbol{B}, \boldsymbol{E}, 50 \mu \mathrm{m} ; \boldsymbol{D}, 500 \mu \mathrm{m}$.

differentiation, and its cKO inhibits OL differentiation; (4) TCF7l2 regulates OL differentiation without modulating $\mathrm{Wnt} / \beta$ catenin signaling but instead may antagonize inhibition of OL differentiation mediated by BMP/Smad signaling (Grinspan et al., 2000; Samanta and Kessler, 2004; See et al., 2004); and (5) TCF712 reinduction after myelin damage promotes OL differentiation during remyelination. Results presented here weaken the hypothesis that TCF712 expression inhibits OL differentiation through activation of $\mathrm{Wnt} / \beta$-catenin signaling. Our experimental data also indicate that the sparse expression of TCF712 in active lesions of multiple sclerosis (Fancy et al., 2009; Pedre et al., 2011; Lürbke et al., 2013) may play a Wnt-independent role, and TCF712 expression may be an indicator of the occurrence of OL differentiation rather than a sign of blockage of OL differentiation.

It is well accepted that oligodendroglial lineage cells express TCF712 among the four members of Wnt effector TCF/LEF1 family. One laboratory found that TCF7l2 is expressed specifically in PDGFR $\alpha^{+}$OPCs but not in exon 3b-containing Plp mRNA $^{+}$mature OLs (Fancy et al., 2009, 2011). However, our data agree with the reports by Fu et al. (2009) who found that TCF712 is restricted to postmitotic premyelinating OLs and is absent in OPCs in the mixed glial cultures from neonate cortex and by Ye et al. (2009) who reported that TCF7l2 is upregulated in $\mathrm{CCl}^{+}$differentiated OLs. A recent study in human tissue (Lürbke et al., 2013) also reported TCF712 expression in mature OLs. The issue of the temporal dynamics of TCF712 expression is important because it has been assumed that TCF712 is linked to the activation of Wnt $/ \beta$-catenin signaling in OPCs. Our data do not support a link between TCF7l2 expression and Wnt $/ \beta$ catenin signaling activation in oligodendroglial lineage cells (both OPCs and OLs). First, conditional disruption of $\beta$-catenin affected neither the OL differentiation (Lang et al., 2013) nor the expression of the Wnt target gene Axin2 (Fig. 8I) and TCF712 (data not shown). Second, conditional disruption of the Wnt inhibitor APC inhibited OL differentiation, activated Wnt $/ \beta$ catenin signaling, and, conversely, downregulated TCF712 expression (Fig. $1 B-D$ ). Third, using the Wnt reporter mouse strains Bat-LacZ and Axin2-LacZ, we found that TCF712 expression was not correlated with activation of Wnt signaling (Fig. 4). Fourth, Axin $2 \mathrm{mRNA}$, a reliable marker for Wnt activation, was not detected in TCF712 ${ }^{+}$OLs (Fig. 1 I,J), consistent with a recent study (Fancy et al., 2014). Finally, conditional disruption of TCF712 did not affect Wnt signaling activity in either neonatal or postnatal oligodendroglial lineage cells (Fig. $8 B-E, H$ ). Collectively, our data suggest that neonatal and postnatal oligodendroglial lineage cells do not respond to Wnt signaling through TCF7l2 in vivo. 
Wnt/ $\beta$-catenin signaling has been shown to inhibit both oligodendrogenesis and OL differentiation. Based on the fact that TCF712 is the Wnt effector expressed in oligodendroglial lineage cells (Fancy et al., 2009; Fu et al., 2009; Ye et al., 2009), it has been long accepted that TCF712 inhibits OL differentiation through activation of Wnt/ $\beta$-catenin signaling (He et al., 2007; Fancy et al., 2009, 2011; Li et al., 2009; Freese et al., 2010; Kotter et al., 2011). An early study suggested that TCF7l2 mediated the inhibition of OL differentiation caused by YY1 cKO (He et al., 2007; Li et al., 2009). In support of that suggestion, overexpression of TCF712 in an immortalized OPC cell line inhibited the luciferase activity driven by the Mbp promoter (He et al., 2007). However, it is possible that overexpression of full-length TCF712 in that progenitor cell line created an in vitro "pathological" environment (note that TCF712 expression is high in newly differentiated OLs in vivo) in which it inappropriately activated and potentiated Wnt $/ \beta$-catenin activity, leading to the inhibition of transfected $M b p$ promoter activity (He et al., 2007). It has been reported that PDGF, which is included in the culture medium or is present in serum supplement to the culture medium, stimulates the activity of Wnt/ $\beta$-catenin signaling in OPC culture systems (Chew et al., 2011). Subsequently, Ye et al. (2009) reported that expression of a dominant-negative TCF7l2 that lacks a $\beta$-catenin-binding domain (thus blocking the Wnt-related function of TCF712) accelerated oligodendrogenesis in chick embryos. However, it is not clear whether this precocious oligodendrogenesis was attributable to the inactivation of the Wnt-related function of TCF712 or the activation of the Wnt-independent role of TCF712, for example repressing BMP signaling activation as we reported here (Fig. $8 D, F, G)$. Alternatively, precocious oligodendrogenesis may have been a consequence of an "ectopic" effect of dominant-negative TCF712 overexpression, because dominant-negative forms of TCF7l2 devoid of $\beta$-catenin-binding domain are, unlike in embryonic brain, normally absent in the embryonic spinal cord (Vacik et al., 2011; Nagalski et al., 2013). A previous study showed that TCF712 is also expressed in neural stem cells (NSCs), including Olig2 ${ }^{+}$OPC-generating NSCs in embryonic spinal cord before oligodendrogenesis (Wang et al., 2011). Thus, in the future, it would be interesting to assess whether TCF712 cKO affects embryonic oligodendrogenesis and, if yes, whether through modulating Wnt signaling, BMP signaling, or both.

Our study has focused on the neonatal and postnatal oligodendroglial lineage and demonstrates that the Wnt-related function of TCF712 plays a minor role, if any, in OL differentiation. Most importantly, we show that, contrary to the well accepted hypothesis, TCF712 functions as a positive regulator of OL differentiation during both developmental myelination and remyelination. This conclusion concerning the role of TCF712 in OL differentiation is compatible with data derived from $T c f 7 l 2$-null late embryos or newborns (Fu et al., 2009; Ye et al., 2009).

Our gene deletion data suggest, for the first time, a novel link between TCF712 and repression of BMP signaling in the context of the in vivo oligodendroglial lineage. BMP signaling is an inhibitory pathway for oligodendrogenesis and OL differentiation (Grinspan et al., 2000; Samanta and Kessler, 2004; See et al., 2004). The source of BMP ligands has not been established definitively. However, oligodendroglial lineage cells have been shown to secrete BMPs (Kondo and Raff, 2004; Ara et al., 2008; Choe et al., 2014), and BMPs may act in an autocrine manner to affect OL differentiation. Interestingly, BMP4, the most abundant BMP ligand in the CNS, is expressed in OPCs (Choe et al., 2014), significantly upregulated in newly formed OLs, and downregulated in myelinating OLs (Zhang et al., 2014). The genetic data presented here suggest that TCF712 antagonizes autocrine oligodendroglial BMP signaling to regulate the timing of OL differentiation. Our study also suggests that, when interpreting the data derived from ectopic expression of the dominant-negative TCF712 lacking the $\beta$-catenin-binding domain (Ye et al., 2009; Tawk et al., 2011), the previously unrecognized BMP-related role of TCF712, as shown here, should be considered. We are currently investigating how TCF712 antagonizes BMP signaling in oligodendroglial lineage cells and whether this antagonistic regulation of TCF712 and BMP signaling also plays a role in embryonic oligodendrogenesis.

Expression of the myelin genes $\mathrm{Plp}$ and $\mathrm{Mbp}$ was downregulated significantly in the Olig2-CreER ${ }^{T 2}, T c f 7 l 2^{\mathrm{fl} / \mathrm{fl}} \mathrm{cKO}$ system (Figs. $6 D, E, 8 B$ ) in which TCF7l2 is initially ablated predominantly in OPCs but was unaltered in the $P l p-C r e E R T 2, T c f 7 l 2^{\mathrm{fl} / \mathrm{fl}}$ cKO system in which TCF7l2 is initially ablated predominantly in OLs (Fig. $7 B, E$ ). This is quite unexpected considering that expression of dominant-negative TCF712 lacking a $\beta$-cateninbinding domain in differentiated OLs directly inactivates $P l p$ and $M b p$ genes in vitro and in zebrafish embryonic spinal cord (Tawk et al., 2011). Our data suggest that TCF712 exerts a stagedependent role during OL development. That is, in postmitotic OPCs that are committed to differentiation and immature OLs in which myelin genes are not fully activated, TCF7l2 may cooperate with other (transcription) factors to activate myelin gene expression to promote OL differentiation, whereas in newly differentiated, myelin gene-expressing OLs, high levels of TCF712 may promote terminal maturation and myelination by enhancing lipid synthesis (Chrast et al., 2011). In this context, we found that Elovl1, a fatty acid elongase essential for the synthesis of C24 fatty acids (Ohno et al., 2010) that are highly enriched in myelin lipid (Chrast et al., 2011), is significantly downregulated in the $P l p$ CreERT2 Tcf7l $2^{\mathrm{fl} / \mathrm{fl}} \mathrm{cKO}$ system at both $24 \mathrm{~h}$ and $7 \mathrm{~d}$ after Tcf7l2 cKO in OLs (Fig. $7 H$ ). Of note, many genes involved in lipid metabolism are direct target genes of TCF7l2 in the liver, and their expression is impaired in Tcf7l2-null newborn livers (Boj et al., 2012). Among all the myelin genes we assessed (Fig. 7E) in the TCF712-disrupted OLs, only MAG, which serves as a signaling molecule between myelin and axons (Yin et al., 1998; Pernet et al., 2008), is significantly altered (Fig. 7G). Additional studies are needed to elucidate the function of TCF712 in differentiated OLs and its link to lipid metabolism and MAG expression for the terminal myelination event.

\section{References}

Anastas JN, Moon RT (2013) WNT signalling pathways as therapeutic targets in cancer. Nat Rev Cancer 13:11-26. CrossRef Medline

Angus-Hill ML, Elbert KM, Hidalgo J, Capecchi MR (2011) T-cell factor 4 functions as a tumor suppressor whose disruption modulates colon cell proliferation and tumorigenesis. Proc Natl Acad Sci U S A 108:49144919. CrossRef Medline

Aoki K, Taketo MM (2007) Adenomatous polyposis coli(APC): a multi-functional tumor suppressor gene. J Cell Sci 120:3327-3335. CrossRef Medline

Ara J, See J, Mamontov P, Hahn A, Bannerman P, Pleasure D, Grinspan JB (2008) Bone morphogenetic proteins 4, 6, and 7 are up-regulated in mouse spinal cord during experimental autoimmune encephalomyelitis. J Neurosci Res 86:125-135. CrossRef Medline

Barker N, Huls G, Korinek V, Clevers H (1999) Restricted high level expression of Tcf-4 protein in intestinal and mammary gland epithelium. Am J Pathol 154:29-35. CrossRef Medline

Boj SF, van Es JH, Huch M, Li VS, José A, Hatzis P, Mokry M, Haegebarth A, van den Born M, Chambon P, Voshol P, Dor Y, Cuppen E, Fillat C, Clevers H (2012) Diabetes risk gene and Wnt effector Tcf712/TCF4 controls hepatic response to perinatal and adult metabolic demand. Cell 151: 1595-1607. CrossRef Medline

Chew LJ, Shen W, Ming X, Senatorov VV Jr, Chen HL, Cheng Y, Hong E, Knoblach S, Gallo V (2011) SRY-box containing gene 17 regulates the 
Wnt/beta-catenin signaling pathway in oligodendrocyte progenitor cells. J Neurosci 31:13921-13935. CrossRef Medline

Choe Y, Huynh T, Pleasure SJ (2014) Migration of oligodendrocyte progenitor cells is controlled by transforming growth factor beta family proteins during corticogenesis. J Neurosci 34:14973-14983. CrossRef Medline

Chrast R, Saher G, Nave KA, Verheijen MH (2011) Lipid metabolism in myelinating glial cells: lessons from human inherited disorders and mouse models. J Lipid Res 52:419-434. CrossRef Medline

Dai ZM, Sun S, Wang C, Huang H, Hu X, Zhang Z, Lu QR, Qiu M (2014) Stage-specific regulation of oligodendrocyte development by Wnt/betacatenin signaling. J Neurosci 34:8467-8473. CrossRef Medline

Doerflinger NH, Macklin WB, Popko B (2003) Inducible site-specific recombination in myelinating cells. Genesis 35:63-72. CrossRef Medline

Fancy SP, Baranzini SE, Zhao C, Yuk DI, Irvine KA, Kaing S, Sanai N, Franklin RJ, Rowitch DH (2009) Dysregulation of the Wnt pathway inhibits timely myelination and remyelination in the mammalian CNS. Genes Dev 23:1571-1585. CrossRef Medline

Fancy SP, Kotter MR, Harrington EP, Huang JK, Zhao C, Rowitch DH, Franklin RJ (2010) Overcoming remyelination failure in multiple sclerosis and other myelin disorders. Exp Neurol 225:18-23. CrossRef Medline

Fancy SP, Harrington EP, Yuen TJ, Silbereis JC, Zhao C, Baranzini SE, Bruce CC, Otero JJ, Huang EJ, Nusse R, Franklin RJ, Rowitch DH (2011) Axin2 as regulatory and therapeutic target in newborn brain injury and remyelination. Nat Neurosci 14:1009-1016. CrossRef Medline

Fancy SP, Harrington EP, Baranzini SE, Silbereis JC, Shiow LR, Yuen TJ, Huang EJ, Lomvardas S, Rowitch DH (2014) Parallel states of pathological Wnt signaling in neonatal brain injury and colon cancer. Nat Neurosci 17:506-512. CrossRef Medline

Feigenson K, Reid M, See J, Crenshaw EB 3rd, Grinspan JB (2009) Wnt signaling is sufficient to perturb oligodendrocyte maturation. Mol Cell Neurosci 42:255-265. CrossRef Medline

Freese JL, Pino D, Pleasure SJ (2010) Wnt signaling in development and disease. Neurobiol Dis 38:148-153. CrossRef Medline

Fu H, Cai J, Clevers H, Fast E, Gray S, Greenberg R, Jain MK, Ma Q, Qiu M, Rowitch DH, Taylor CM, Stiles CD (2009) A genome-wide screen for spatially restricted expression patterns identifies transcription factors that regulate glial development. J Neurosci 29:11399-11408. CrossRef Medline

Fu H, Kesari S, Cai J (2012) Tcf7l2 is tightly controlled during myelin formation. Cell Mol Neurobiol 32:345-352. CrossRef Medline

Grinspan JB, Edell E, Carpio DF, Beesley JS, Lavy L, Pleasure D, Golden JA (2000) Stage-specific effects of bone morphogenetic proteins on the oligodendrocyte lineage. J Neurobiol 43:1-17. CrossRef Medline

Guo F, Ma J, McCauley E, Bannerman P, Pleasure D (2009) Early postnatal proteolipid promoter-expressing progenitors produce multilineage cells in vivo. J Neurosci 29:7256-7270. CrossRef Medline

Guo F, Maeda Y, Ma J, Delgado M, Sohn J, Miers L, Ko EM, Bannerman P, Xu J, Wang Y, Zhou C, Takebayashi H, Pleasure D (2011) Macroglial plasticity and the origins of reactive astroglia in experimental autoimmune encephalomyelitis. J Neurosci 31:11914-11928. CrossRef Medline

Guo F, Maeda Y, Ko EM, Delgado M, Horiuchi M, Soulika A, Miers L, Burns T, Itoh T, Shen H, Lee E, Sohn J, Pleasure D (2012) Disruption of NMDA receptors in oligodendroglial lineage cells does not alter their susceptibility to experimental autoimmune encephalomyelitis or their normal development. J Neurosci 32:639-645. CrossRef Medline

Harlow DE, Saul KE, Culp CM, Vesely EM, Macklin WB (2014) Expression of proteolipid protein gene in spinal cord stem cells and early oligodendrocyte progenitor cells is dispensable for normal cell migration and myelination. J Neurosci 34:1333-1343. CrossRef Medline

He Y, Dupree J, Wang J, Sandoval J, Li J, Liu H, Shi Y, Nave KA, Casaccia-Bonnefil P (2007) The transcription factor Yin Yang 1 is essential for oligodendrocyte progenitor differentiation. Neuron 55:217-230. CrossRef Medline

Kondo T, Raff MC (2004) A role for Noggin in the development of oligodendrocyte precursor cells. Dev Biol 267:242-251. CrossRef Medline

Kotter MR, Stadelmann C, Hartung HP (2011) Enhancing remyelination in disease - can we wrap it up? Brain 134:1882-1900. CrossRef Medline

Lang J, Maeda Y, Bannerman P, Xu J, Horiuchi M, Pleasure D, Guo F (2013) Adenomatous polyposis coli regulates oligodendroglial development. J Neurosci 33:3113-3130. CrossRef Medline

Lappe-Siefke C, Goebbels S, Gravel M, Nicksch E, Lee J, Braun PE, Griffiths IR, Nave KA (2003) Disruption of Cnp1 uncouples oligodendroglial functions in axonal support and myelination. Nat Genet 33:366-374. CrossRef Medline

Li H, He Y, Richardson WD, Casaccia P (2009) Two-tier transcriptional control of oligodendrocyte differentiation. Curr Opin Neurobiol 19:479_ 485. CrossRef Medline

Lie DC, Colamarino SA, Song HJ, Désiré L, Mira H, Consiglio A, Lein ES, Jessberger S, Lansford H, Dearie AR, Gage FH (2005) Wnt signalling regulates adult hippocampal neurogenesis. Nature 437:1370-1375. CrossRef Medline

Lien WH, Fuchs E (2014) Wnt some lose some: transcriptional governance of stem cells by Wnt/beta-catenin signaling. Genes Dev 28:1517-1532. CrossRef Medline

Lürbke A, Hagemeier K, Cui QL, Metz I, Brück W, Antel J, Kuhlmann T (2013) Limited TCF7L2 expression in MS lesions. PLoS One 8:e72822. CrossRef Medline

Maretto S, Cordenonsi M, Dupont S, Braghetta P, Broccoli V, Hassan AB, Volpin D, Bressan GM, Piccolo S (2003) Mapping Wnt/beta-catenin signaling during mouse development and in colorectal tumors. Proc Natl Acad Sci U S A 100:3299-3304. CrossRef Medline

Nagalski A, Irimia M, Szewczyk L, Ferran JL, Misztal K, Kuznicki J, Wisniewska MB (2013) Postnatal isoform switch and protein localization of LEF1 and TCF7L2 transcription factors in cortical, thalamic, and mesencephalic regions of the adult mouse brain. Brain Struct Funct 218:15311549. CrossRef Medline

Ohno Y, Suto S, Yamanaka M, Mizutani Y, Mitsutake S, Igarashi Y, Sassa T, Kihara A (2010) ELOVL1 production of C24 acyl-CoAs is linked to C24 sphingolipid synthesis. Proc Natl Acad Sci U S A 107:18439-18444. CrossRef Medline

Pedre X, Mastronardi F, Bruck W, López-Rodas G, Kuhlmann T, Casaccia P (2011) Changed histone acetylation patterns in normal-appearing white matter and early multiple sclerosis lesions. J Neurosci 31:3435-3445. CrossRef Medline

Pernet V, Joly S, Christ F, Dimou L, Schwab ME (2008) Nogo-A and myelinassociated glycoprotein differently regulate oligodendrocyte maturation and myelin formation. J Neurosci 28:7435-7444. CrossRef Medline

Sabo JK, Cate HS (2013) Signalling pathways that inhibit the capacity of precursor cells for myelin repair. Int J Mol Sci 14:1031-1049. CrossRef Medline

Samanta J, Kessler JA (2004) Interactions between ID and OLIG proteins mediate the inhibitory effects of BMP4 on oligodendroglial differentiation. Development 131:4131-4142. CrossRef Medline

See J, Zhang X, Eraydin N, Mun SB, Mamontov P, Golden JA, Grinspan JB (2004) Oligodendrocyte maturation is inhibited by bone morphogenetic protein. Mol Cell Neurosci 26:481-492. CrossRef Medline

Shimizu T, Kagawa T, Wada T, Muroyama Y, Takada S, Ikenaka K (2005) Wnt signaling controls the timing of oligodendrocyte development in the spinal cord. Dev Biol 282:397-410. CrossRef Medline

Swiss VA, Nguyen T, Dugas J, Ibrahim A, Barres B, Androulakis IP, Casaccia P (2011) Identification of a gene regulatory network necessary for the initiation of oligodendrocyte differentiation. PLoS One 6:e18088. CrossRef Medline

Tawk M, Makoukji J, Belle M, Fonte C, Trousson A, Hawkins T, Li H, Ghandour S, Schumacher M, Massaad C (2011) Wnt/ $\beta$-Catenin signaling is an essential and direct driver of myelin gene expression and myelinogenesis. J Neurosci 31:3729-3742. CrossRef Medline

Vacik T, Stubbs JL, Lemke G (2011) A novel mechanism for the transcriptional regulation of Wnt signaling in development. Genes Dev 25:17831795. CrossRef Medline

Wang H, Lei Q, Oosterveen T, Ericson J, Matise MP (2011) Tcf/Lef repressors differentially regulate Shh-Gli target gene activation thresholds to generate progenitor patterning in the developing CNS. Development 138: 3711-3721. CrossRef Medline

Wisniewska MB, Nagalski A, Dabrowski M, Misztal K, Kuznicki J (2012) Novel beta-catenin target genes identified in thalamic neurons encode modulators of neuronal excitability. BMC Genomics 13:635. CrossRef Medline

Wood TL, Bercury KK, Cifelli SE, Mursch LE, Min J, Dai J, Macklin WB (2013) mTOR: a link from the extracellular milieu to transcriptional regulation of oligodendrocyte development. ASN Neuro 5:e00108. CrossRef Medline

YeF, Chen Y, Hoang T, Montgomery RL, Zhao XH, Bu H, Hu T, Taketo MM, van Es JH, Clevers H, Hsieh J, Bassel-Duby R, Olson EN, Lu QR (2009) HDAC1 and HDAC2 regulate oligodendrocyte differentiation by disrupting the beta-cateninTCF interaction. Nat Neurosci 12:829-838. CrossRef Medline

Yin X, Crawford TO, Griffin JW, Tu Ph, Lee VM, Li C, Roder J, Trapp BD (1998) Myelin-associated glycoprotein is a myelin signal that modulates the caliber of myelinated axons. J Neurosci 18:1953-1962. Medline

Zhang Y, Chen K, Sloan SA, Bennett ML, Scholze AR, O'Keeffe S, Phatnani HP, Guarnieri P, Caneda C, Ruderisch N, Deng S, Liddelow SA, Zhang C, Daneman R, Maniatis T, Barres BA, Wu JQ (2014) An RNA-sequencing transcriptome and splicing database of glia, neurons, and vascular cells of the cerebral cortex. J Neurosci 34:11929-11947. CrossRef Medline 